Annales Missiologici Posnanienses t. 19 (2014), s. 137-166

DOI: $10.14746 / \mathrm{amp} .2014 .19 .6$

WOJCIECH KLUJ

Wydział Teologiczny Uniwersytetu Kardynała Stefana Wyszyńskiego, Warszawa

\title{
Pole pracy misji ad gentes Misjonarzy Oblatów Maryi Niepokalanej w XIX wieku w Ameryce Pólnocnej
}

Wstępny projekt Eugeniusza de Mazenoda zapowiadany w Regule z 1818 r., aby ewangelizować ludzi na całej ziemi, został zrealizowany w $1841 \mathrm{r}$. Zgromadzenie Misjonarzy Oblatów Maryi Niepokalanej, założone w 1816 r., było wówczas wciąż bardzo małe (ok. 50 członków), jednak oblaci skierowali pierwszych misjonarzy poza granice Francji, do Anglii i Kanady, a z czasem objęli placówki misyjne w Stanach Zjednoczonych oraz innych krajach misyjnych, od południowej Afryki po Cejlon (Sri Lankę).

Przedmiotem niniejszego artykułu będzie opis terytorialnej ekspansji misji oblackich na kontynencie północnoamerykańskim w XIX w. ${ }^{1}$ Wymiar geograficzny wciąż jest ważnym elementem określenia działalności misyjnej. Prezentowany tekst został opracowany w głównej mierze na podstawie dotychczasowych ustaleń historiografii zakonnej, której trzonem są prace oblatów kanadyjskich. Zajmowali się oni dogłębnie zagadnieniem niezwykle dynamicznego rozwoju terytorialnego zgromadzenia oblatów w Ameryce Północnej, zwłaszcza w Kanadzie w XIX w. Temat ten podejmowano także w Polsce w kontekście studiów nad działalnością misyjną Kościoła katolickiego w specyficznych regionach Kanady, np. subarktycznych i arktycznych ${ }^{2}$. Istnieją ponadto prace współczesnych autorów kanadyjskich podejmujące zagadnienie

\footnotetext{
${ }^{1}$ Pisząc o Kanadzie i Stanach Zjednoczonych, odnoszę się do tych krajów w ich współczesnych granicach bez podejmowania złożonego zagadnienia kształtowania się obu struktur administracyjno-państwowych w ciągu XIX w. Literatura na ten temat jest obfita, dobrym punktem wyjścia może być http://www.thecanadianencyclopedia.ca/en/article/canadian-american-relations/ [dostęp 2.10.2014].

${ }^{2}$ Por. P. Zając, Spotkania kultur. Katoliccy misjonarze i Ludność Rodzima w Kanadzie w historiografii XIX i XX w. Warszawa 2007; tenże, Kościót katolicki za Kolem Polarnym. Misjonarze Oblaci Maryi Niepokalanej w centralnej Arktyce kanadyjskiej, 1912-2012, Kraków 2012.
} 
rozwoju terytorialnego misji oblackich, zwłaszcza w zachodniej Kanadzie ${ }^{3}$. Niniejsze całościowe opracowanie ma być bardziej syntetycznym podsumowaniem tematyki i przygotowaniem do dalszych analiz misjologicznych ${ }^{4}$.

\section{Wschodnia Kanada ${ }^{5}$}

Eugeniusz de Mazenod posłał oblatów do pracy w Kanadzie na zaproszenie bp. Bourgeta z diecezji montrealskiej. Pierwsza grupa oblatów dotarła do Montrealu 2 grudnia $1841 \mathrm{r}^{6}{ }^{6}$ Diecezja ta wiele zawdzięcza działalności oblatów. Wizytator superiora generalnego o. Soullier pisał w akcie wizytacyjnym z 1876 r., że dom pw. św. Piotra Apostoła w Montrealu jest „ośrodkiem gorliwości, której promieniowanie rozciąga się na całą Kanadę i często poza nią" "7. Była to jednak działalność właściwie duszpasterska, a nie misyjna. Do działalności misyjnej można zaliczyć co najwyżej prowadzenie misji Le Sault-St-Louis w Caughnawaga (wśród Indian), którą bp Bourget powierzył oblatom w 1855 r., a która w roku 1892 została oddana duchowieństwu diecezjalnemu ${ }^{8}$. O wiele znaczniejsze zaangażowanie misyjne oblaci podjęli w diecezji Québec i ottawskiej.

\section{Diecezja Québec}

Działalność oblatów w tej diecezji także obejmowała wiele dzieł, niekoniecznie misyjnych, np. posługę duszpasterską w parafii pw. Zbawiciela w Québecu, misje ludowe czy pracę wśród białych osadników i pracowników wyrębów leśnych nad rzekami Świętego Maurycego i Saguenay oraz na północnym nabrze-

${ }^{3}$ Por. R. Choquette, The Oblate Assault on Canada's Northwest, Ottawa 1995.

${ }^{4}$ Artykuł jest kontynuacją moich studiów opublikowanych w poprzednich numerach „Annales Missiologici Posnanienses" (dalej cyt. jako AMis): Pole pracy Misjonarzy Oblatów Maryi Niepokalanej na Cejlonie w XIX w., „Annales Missiologici Posnanienses” 17 (2010), s. 51-68; oraz Pole pracy Misjonarzy Oblatów Maryi Niepokalanej w Afryce w XIX w., „Annales Missiologici Posnanienses" 18 (2012), s. 113-128.

${ }^{5}$ W 1908 r. obszar ten został wyjęty spod jurysdykcji Kongregacji Rozkrzewiania Wiary. W połowie XIX w. istniały tam trzy diecezje: Québec, Montreal i Ottawa. Por. A. Baran, Provision for the Canadian Church. Further development after 1840, w: Memoria Rerum Sacrae Congregations de Propaganda Fide. 350 anni a servizio delle Missioni, 1622-1972, t. 3/1, red. J. Metzler, Rome 1972, s. 756.

${ }^{6}$ Por. H. Gratton, 1841 - A la naissance de nos missions canadiennes, „Études Oblates. Revue trimestrielle publiée par les Oblats de Marie Immaculée de la Province du Canada" [dalej cyt. jako: EO] 1(1942), s. 100-117 oraz E. de Mazenod, Lettres d'obédience des premiers missionnaires Oblats au Canada, EO 1 (1942), s. 124-128 (teksty w j. łacińskim).

${ }^{7}$ D. Levasseur, Histoire des Missionnaires Oblats de Marie Immaculée. Essai de synthèse, t. 1: 1815-1898, Montreal 1983, s. 208.

${ }^{8}$ Por. tamże, s. 204. 
żu Rzeki Świętego Wawrzyńca. Jednak dekretem z 4 października 1844 r. abp Joseph Signay skierował ich także do posługi wśród Indian ${ }^{9}$. Mieli ewangelizować grupy na północnym nabrzeżu Rzeki Świętego Wawrzyńca (Betsiamits), w głębi Labradoru (Misstassins) oraz na północy Labradoru (Montagnais) ${ }^{10}$. Pierwszą rezydencję $e^{11}$ dla misjonarzy założono w 1844 r. w St-Alexis-de-la-Grande-Baie nad rzeką Saguenay ${ }^{12}$. Później była ona dwukrotnie przenoszona. Najpierw w 1851 r. do Escoumins, a definitywnie w 1862 r. do Betsiamits. Druga rezydencja została otwarta w Pointe-Bleue nad Jeziorem Świętego Ja$n^{13}$. Z domów tych oblaci odwiedzali wiele miejsc na północnym nabrzeżu. Z ważniejszych można wymienić: Tadoussac, Portneuf, Islets-de-Jéremie, Betsiamits, Godbout, Sept-Iles, Mingan, Itamamiou czy wreszcie Blanc-Sablon. Gdy w 1892 r. biskupem diecezji Chicoutimi został Michel-Thomas Labrecque, oblaci opuścili część tych terenów na rzecz kapłanów diecezjalnych ${ }^{14}$.

Podejmowane też były odległe wyprawy misyjne w głąb Labradoru do szczepu Misstassins (Naskapis). Pierwszą taką eskapadę podjął o. Arnaud w roku 1853. Widzialnym skutkiem tych działań było założenie w North West River nad Baie-des-Esquimaux misji, która od roku 1871 miała własną kaplicę. W latach 1872-1882 misjonarze docierali aż do Fort Chimo nad Zatoką Unga$\mathrm{va}^{15}$. Projekt założenia tam rezydencji nie mógł zostać zrealizowany z braku

${ }^{9}$ Por. D. Levasseur, Histoire des Missionnaires Oblats de Marie Immaculée, dz. cyt., s. 128. Na temat genezy obecności Kościoła katolickiego we wschodniej Kanadzie por. L. Campeau, Les initiatives de la S. Congrégation en faveur de la Nouvelle France, w: Memoria Rerum..., dz. cyt., t. 1/2, s. 764-778.

${ }^{10}$ Por. V. Tremblay, Les Oblats au Saguenay, EO 3 (1944), s. 7-8.

${ }^{11}$ Zakonnicy żyją w domach zakonnych. W różnych opracowaniach wykorzystywanych w tej pracy określenia „dom”, „rezydencja”, „placówka” i „stacja” bywają często stosowane zamiennie i nieraz trudno dociec, co dany autor miał na myśli. Dla pewnego ujednolicenia w niniejszej pracy nazwy „dom” i „rezydencja” używane są zgodnie z tradycją przyjętą w zgromadzeniu. Mianowicie jako „dom” określane są większe siedziby, mniejsze zaś nazywane są „rezydencjami”. W rezydencji często mieszkał jeden misjonarz.

${ }^{12}$ Nazwą Saguenay określane bywają dwa regiony: (a) okolice Jeziora Świętego Jana i rzeki Saguenay oraz (b) północne nabrzeże Rzeki Świętego Wawrzyńca aż po Labrador.

${ }^{13}$ Por. P. Scharsch, Geschichte der Kongregation der Oblaten der Heiligsten und Unbeflecten Jungfrau Maria von ihrem Anfange bis zum Tode des dritten Generalobern, 1816-1897, Bd. 2: Unter den Generalobern P. Joseph Fabre und P. Louis Soullier, 1861-1897, Maria Engelport 1952, s. 189; État général du Personnel de la Congrégation des Missionnaires Oblats de Marie Immaculée, no. 5 - Avril 1899, Paris [1899] [dalej cyt. jako: Personnel 1899], s. 39.

${ }^{14}$ Więcej miejsc wraz ze stacjami pomocniczymi znaleźć można: G. Carrière, Histoire documentaire de la Congrégation des Missionnaires Oblats de Marie-Immaculée dans l'Est du Canada, t. 3, Ottawa 1961, s. 297-349 oraz tenże, Les Oblats de M.I. dans le Vicariat Apostolique du Labrador (1844-1959), Ottawa 1958, s. 51-68. Por. także V. Tremblay, Les Oblats au Saguenay, dz. cyt., s. 17.

${ }^{15}$ Por. G. Carrière, Les Oblats..., dz. cyt., s. 82-88; D. Levassuer, Histoire des Missionnaires Oblats de Marie Immaculée, dz. cyt., t. 1, s. 129; P. Scharsch, Geschichte der Kongregation der Oblaten der Heiligsten und Unbeflecten Jungfrau Maria, Bd. 2, dz. cyt., s. 204-206. Por. bardzo szczegółowy dziennik podróży o. Arnaud w głąb Labradoru w 1872 r. wraz z wymienionymi miejscami: C. Ar- 
środków finansowych. Biskupi kanadyjscy wielokrotnie zwracali się do zgromadzenia, by przyjęło te tereny jako swoje misje. $\mathrm{Z}$ powodu braku misjonarzy trzeba było odmawiać, ale kontynuowano rozpoczęte prace. Dopiero na początku XX w. obszar ten został przez zgromadzenie przyjęty jako teren misyjny ${ }^{16}$.

Drugim rejonem był region Rzeki Świętego Maurycego i Jeziora Świętego Jana. We wspomnianym wyżej dekrecie bp. Signay chodziło również o Indian tego terenu. Nie udało się tam, mimo staran, założyć rezydencji dla misjonarzy. $Z$ domów Maniwaki i Témiscamingue ewangelizowano w licznych miejscach, począwszy już od roku 1844. Obszar omawiany w tej części rozciąga się na północ, aż poza źródła Rzeki Świętego Maurycego. $\mathrm{Z}$ ważniejszych miejscowości tego regionu można wymienić: Warmontaching, Kikendache, Mékiskan, Assoapemochan, Wassanipi, Mitakanabikong, Lac Mistassini, Obedjiwan, Chomochouwan i Kakipongang ${ }^{17}$.

\section{Diecezja Ottawa (Bytown)}

W 1844 r. bp Bourget w porozumieniu z biskupem diecezji Kingston osiedlił oblatów w Bytown. Miasto to leżało przy granicy diecezji Montreal, lecz należało do diecezji Kingston. Na prośbę biskupów kanadyjskich w 1847 r. Stolica Apostolska erygowała diecezję Bytown i mianowała o. Guigues’a OMI jej biskupem ${ }^{18}$. Oblaci pracowali zarówno w samej Ottawie, jak i w okolicy: w Hull ${ }^{19}$, w South-Gloucester, w l'Orginal, ale było to raczej duszpasterstwo, choć połączone z zakładaniem parafii. Omawianie pracy misyjnej w tej diecezji, dla większej jasności, lepiej podzielić na dwie części związane z dwoma regionami. Pierwszy to okolice rzeki Gatineau. W 1851 r. został założony dom w Maniwaki, lecz misjonarze pracowali tam już od roku $1848^{20}$. Głosi-

naud, Journal de voyage au Labrador, ,Vie Oblate Life. Revue trimestrielle publiée par les Oblats de Marie Immaculée de la Province St-Joseph" [dalej cyt. jako: VOL] 34 (1975), s. 45-110.

${ }^{16}$ Por. D. Levasseur, Histoire des Missionnaires Oblats de Marie Immaculée, dz. cyt., t. 1, s. 303-304. Por. też G. Carrière, Histoire documentaire de la Congrégation des Missionnaires Oblats de Marie-Immaculée dans l'Est du Canada, t. 9, Ottawa 1970, s. 55-127.

${ }^{17}$ Inne mniejsze wymienia G. Carrière, Histoire documentaire, dz. cyt., t. 3, s. 253-290.

${ }^{18}$ Brewem Ad prospiciendum facilius z 25 VI 1847 r. diecezja Bytown stała się sufraganią Québecu. W 1860 r. została zmieniona nazwa diecezji na Ottawa, a w 1886 r. stała się ona metropolią. Por. G. Carrière, Histoire documentaire, dz. cyt., t. 1, s. 294. N. Kowalsky, L'érection du diocèse de Bytown selon les documents des archives de la Propagande, EO 11 (1952), s. 179-187. Pierwszym biskupem został oblat, ale nie było to powierzenie terenów na zasadzie ius commissionis. To, czym mieli się zająć oblaci, regulowała konwencja między biskupami Guigues i de Mazenod. Por. Convention Guigues - de Mazenod, EO 15 (1956), s. 360-364 (tekst tej konwencji).

${ }^{19}$ W 1963 r. powstała diecezja Hull. Od 1982 r. nosi ona nazwę Gatineau-Hull. Por. Annuario, s. 232

${ }^{20}$ Por. G. Carrière, Histoire documentaire de la Congrégation des Missionnaires Oblats de Marie-Immaculée dans l'Est du Canada, t. 7, Ottawa 1968, s. 117. 
li Ewangelię w licznych małych osadach, które z czasem stały się parafiami i zostały oddane duchowieństwu diecezjalnemu ${ }^{21}$, oraz okolicznym Indianom. W latach 1849-1864 oraz 1887-1900 do domu w Maniwaki należeli również misjonarze z regionu Rzeki Świętego Maurycego (por. paragraf poświęcony diecezji Québec). Aż do założenia w 1863 r. domu w Témiscamingue mieli tu także swoją bazę wypadową misjonarze Zatoki Jamesa ${ }^{22}$. Ojciec Carrière wymienia 20 stacji misyjnych zależnych od domu w Maniwaki oraz omawia ich pracę. Z większych można wymienić: La Visitation w Gracefield, St-Gabriel w Bouchette oraz Ste-Famille-d'Aumond ${ }^{23}$. Pole tej działalności trafnie określił prowincjał Kanady na Kapitule Generalnej w 1873 r.: „To właśnie nasi ojcowie z N.-D. du Desért (Maniwaki) ewangelizowali basen rzeki Gatineau. To oni ukształtowali ludność katolicką i utworzyli parafie"24.

Drugi obszar to tereny od jeziora Témiscamingue po Zatokę Jamesa. Już w maju 1844 r. bp Bourget powierzył młodemu o. Laverlochèrowi pracę wśród Indian rozproszonych od Bytown aż po jeziora Témiscamingue i Abitibi. W roku 1847 razem ze współbraćmi wziął w opiekę Moose Factory (Moosonee), a w roku następnym również Fort Albany ${ }^{25}$. Gdy w 1851 r. został otwarty dom w Maniwaki, miał on służyć także misjonarzom Zatoki Świętego Maurycego oraz Zatoki Jamesa. Odległość była jednak zbyt wielka, więc w 1863 r. otworzono rezydencję St-Claude nad jeziorem Témiscamingue. Kilkakrotnie ją przenoszono i ostatecznie umiejscowiono ją w indiańskim rezerwacie Tête-du-Lac (dzisiejsze Notre-Dame du Nord). Działalność w siedmiu okolicznych stacjach misyjnych omawia o. Carrière ${ }^{26}$.

Rozwiązanie z domem nad jeziorem Témiscamingue było dobre dla misjonarzy pracujących w jego okolicach. Nadal trudno było jednak tym, którzy pracowali nad Zatoką Jamesa. Corocznie musieli pokonywać odległości liczące ok. $2770 \mathrm{~km}$, z tego ponad $1300 \mathrm{~km}$ w kajaku ${ }^{27}$. Odwiedzali stacje misyjne w Longue-Pointe, Abitibi, Timogami, Matatachewanie, Matagami, Grassy-Lake, North River, Kipawie, Bay Lake, Golden Lake ${ }^{28}$. Z myślą o nich została założona w 1892 r. rezydencja w Fort Albany, a w następnym roku w Fort Hope i Winisk.

${ }^{21}$ Por. D. Levasseur, Histoire des Missionnaires Oblats de Marie Immaculée, dz. cyt., t. 1, s. 205.

${ }^{22}$ Por. G. Carrière, Histoire documentaire, dz. cyt., t. 7, s. 147.

${ }^{23}$ Por. tamże, t. 3, s. 99-108 oraz t. 7, s. 151-175.

${ }^{24}$ Rapport de la Province du Canada. Le Chapitre Général de 1873, „Missions de la Congrégation des Missionnaires Oblats de Marie Immaculée” [dalej cyt. jako: „Missions”] 11 (1873), s. 332.

${ }^{25}$ Por. G. Carrière, Histoire documentaire, dz. cyt., t. 3, s. 211-212.

${ }^{26}$ Por. tamże, t. 7, s. 223-249.

27 Por. D. Levasseur, Histoire des Missionnaires Oblats de Marie Immaculée, dz. cyt., t. 1, s. 202-203.

${ }^{28}$ Por. G. Carrière, Histoire documentaire, dz. cyt., t. 7, s. 231. 
Warto wspomnieć, że w innych diecezjach wschodniej Kanady także ofiarowywano oblatom różne prace misyjne. Niestety, z powodu braków personalnych zgromadzenie musiało odmawiać. Przez pierwsze 20 lat, tj. do roku 1861, pracę w swych diecezjach proponowali oblatom biskupi z Toronto, Kingston, London, Hamilton i Charlottetown ${ }^{29}$.

\section{Kanada Zachodnia i Północno-Zachodnia}

O ile w poprzedniej części trzeba było szukać terenów, na których pracowali oblaci, o tyle w tej części trzeba by raczej wyszukiwać tych miejsc, w których nie pracowali. Bez obawy popełnienia błędu można stwierdzić, że cały ten obszar był polem ich działalności misyjnej w XIX w. Dobrze ilustruje to synod prowincji kościelnej St-Boniface (obejmujący cały ten ogromny teren), który się odbył w lipcu 1889 r. Brali w nim udział sami oblaci: abp Taché (z archidiecezji St-Boniface), bp Grandin (z diecezji St-Albert), bp Faraud i bp Clut (wikariusz apostolski Athabaska-Mackenzie), bp Durieu i o. Augier - w zastępstwie bp. D’Herbomeza (wikariusz apostolski Kolumbii Brytyjskiej).

W 1845 r. do St-Boniface przybyli dwaj pierwsi oblaci. Od tego roku można mówić o „wielkiej epopei misjonarskiej”. J.É. Champagne tak ją krótko charakteryzuje: „Najwybitniejszym dziełem tej epopei misjonarskiej nie jest liczba nawróceń, ale zajęcie przez niecałe 15 lat wszystkich punktów strategicznych kraju wielkiego jak kontynent. A ten wspaniały apostolat dokonany został przez małą garść misjonarzy mających do swej dyspozycji tylko bardzo prymitywne ludzkie środki i to jeszcze bardzo ograniczone" ${ }^{\prime 3}$.

To olbrzymie terytorium zostanie omówione według istniejących tam pod koniec XIX w. regionów kościelnych.

\section{Archidiecezja St-Boniface}

Pierwsze próby ewangelizowania tych terenów podjęli jezuici w latach trzydziestych XVIII w. Wkrótce jednak tereny te opuścili ${ }^{31}$. Przez cały czas bezkresne obszary zachodniej i północnozachodniej Kanady należały do diecezji Québec. W 1818 r. bp Plessis utworzył tu specjalny dystrykt i posłał

${ }^{29}$ Por. tenże, Histoire documentaire de la Congrégation des Missionnaires Oblats de Marie-Immaculée dans l'Est du Canada, t. 4, Ottawa 1962, s. 107-127.

30 J.É. Champagne, Les missions catholiques dans l'Ouest canadien (1818-1875), Ottawa 1949, s. 98.

${ }^{31}$ Por. A.G. Morice, Histoire de l'Église catholique dans l'Ouest canadien du Lac Supérieur au Pacifique (1659-1905), t. 1, Winnipeg 1912, s. 23-65. 
ks. Provenchera, który dwa lata później został biskupem. Przez ponad ćwierć wieku, od 1818 do 1844 r. na tym terenie pracowało łącznie 10 kapłanów ${ }^{32}$. W 1844 r. dystrykt Rzeki Czerwonej został erygowany w wikariat apostolski z bp. Provencherem na czele ${ }^{33}$. Rok później przybyli tam oblaci ${ }^{34}$. W ten sposób naturalnym pierwszym obszarem ich pracy w regionie były okolice St. Boniface i Rzeki Czerwonej (Red River, Rivière Rouge) - bp Provencher zlecił oblatom regularne odwiedziny w St-François-Xavier ${ }^{35}$. Z czasem oblaci z domu w St-Boniface zaczęli prowadzić powstające w okolicy parafie: od 1869 r. w Winnipegu ${ }^{36}$; nieco na zachód od Winnipegu pracowali w St-Charles, a na północ od Winnipegu od roku 1879 istniała rezydencja w Selkirk, skąd odwiedzano wiele dalszych stacji misyjnych. Z ważniejszych można wymienić Pequis, Brokenhead (la Tête cassée) czy Whitemouth ${ }^{37}$.

Drugim obszarem, w którym działali oblaci, był region południowowschodni. Już latem 1846 r. o. Aubert spędził półtora miesiąca w Wabassimong, w dorzeczu rzek Winnipeg i Aux Anglais. Rok później objął też swoją działalnością misyjną tereny nad Lac des Bois i Lac la Pluie. Z czasem tamtejszym centrum pracy stała się misja w Fort Alexandre, nad jeziorem Winnipeg, otwarta w roku 1865. Centrum obejmowało obszary aż po Lac des Bois, rzeki la Pluie i Aux Anglais. Misja ta dała początek bardzo ważnej rezydencji w Portage du Rat (dziś Kenora) założonej w roku 1881. W 1893 r. została też ostatecznie założona rezydencja w Fort France, która już wcześniej była odwiedzana ${ }^{38}$.

${ }^{32}$ Nazwiska i czas pracy tych księży podaje np. A. Philippot, L'appel et l'envoi des Oblats de Marie Immaculée dans les „Pays d'En-Haut” (1844-1845), EO 9 (1950), s. 75. Szerzej o początkach tej misji pisze J.É. Champagne, Aux origines de la mission de la rivière Rouge (1818-1845), EO 4 (1945), s. 37-59.

${ }^{33}$ Por. Dom P. Benoît, Vie de Mgr Taché. Archevêque de St-Boniface, t. 1, Montreal 1904, s. 49.

${ }^{34}$ Por. A. Philippot, L'appel et l'envoi des Oblats de Marie Immaculée, dz. cyt., s. 73-98.

${ }^{35}$ Por. T. Ortolan, Cent ans d'Apostolat dans les deux Hémisphères. Les Oblats de Marie Immaculée durant le premier siècle de leur existence, vol. 2: En dehors de l'Europe (jusqu'à la mort du vénéré Fondateur) 1841-1861, Paris 1915, s. 162.

${ }^{36}$ Od 1869 r. parafię pw. Najświętszej Maryi Panny, w latach 1882-1884 nowo powstającą parafię pw. Niepokalanego Poczęcia. Od roku 1899 polscy oblaci prowadzili parafię dla Polaków pw. Ducha Świętego. Por. T. Ortolan, Cent ans d'Apostolat dans les deux Hémisphères. Les Oblats de Marie Immaculée durant le premier siècle de leur existence, Paris 1915-1932, t. 2 : En dehors de l'Europe (jusqu'à la mort du vénéré Fondateur) 1841-1861, s. 287; t. 4 : Au Canada 1861-1892, s. 88 i 92.

${ }^{37}$ Por. Personnel 1899, s. 63; T. Ortolan, Cent ans d'Apostolat dans les deux Hémisphères, dz. cyt., t. 4, s. 93.

38 Por. J.É. Champagne, Nos premieres missions dans l'Ouest canadien (1845-1853), EO 4 (1945), s. 154; État général du Personnel de la Congégation des Missionnaire Oblats de Marie Immaculée, no. 4 - janvier 1895 [dalej cyt. jako: Personnel 1895], Paris 1895, s. 57; Personnel 1899, s. 63. 
W trzecim, północnym regionie, pierwszą placówką była Baie des Canards, gdzie w 1847 r. zamieszkał o. Bermond. W 1849 r. w pobliżu powstała stacja pośrednia Notre-Dame du Lac w St-Laurent, na wschodnim brzegu jeziora Manitoba ${ }^{39}$. Ponieważ pierwsze prace nie przynosiły rezultatów, a brakowało misjonarzy, więc czasowo, do roku 1861, opuszczono te tereny. Omawiając pracę tej misji w latach 1861-1887, Ortolan wymienia 11 stacji misyjnych podlegających Notre-Dame du Lac. Były to: Totogan, Rivière Blanche-Fangeuse (White-Mud River), Baie des Sables (Sandy Bay), Lac du Chien (Dog Lake), le Détroit, Lac du Flux et Reflux (Ebb and Flow), Rivière de la Poule d'eau (Water-Hen), Lac du Cygne (Swan Lake), Rivière Plate (Shoah River), Rivière à la Grue (Crane River), Posen. W 1892 r. w okolicy tej założono dwie rezydencje, w Camperville (Pine Creek) i nad Lac Dauphin ${ }^{40}$.

W czwartym, zachodnim regionie, wskazać należy na dolinę rzeki Qu'Appelle. Pierwszy raz na tereny te zapuścił się bp Taché w 1865 r., który wybrał miejsce pod misję. Została ona założona w roku $1866^{41}$. Miejsce to nazywano początkowo Qu'Appele, dziś jest to Lebret. Rezydencja ta stała się centrum wszystkich stacji misyjnych okolicy. Ortolan wymienia osiem okręgów skupiających te stacje ${ }^{42}$ : (1) Około $50-100 \mathrm{~km}$ na południe były to: Paskwa, Standing Buffalo, Pia-Pot, Blackwood, Indian Head, Broadview, Whitewood, Lac Croche. (2) Pięć stacji misyjnych w okolicy Montagne de la Lime (File Hill), sześć innych w okolicy Montagne de Tondre (Touchwood Hill), dzisiejsze Lestock. (3) Dalej na północny zachód Yellow Quill, Quill Lake (ok. $190 \mathrm{~km}$ ) i White Cap w Moose Woods (ok. 350 km). (4) Bliżej, w kierunku zachodnim (ok. $150 \mathrm{~km}$ ) Moose Jaw (Machoire d'Orignal). (5) Dalej, w kierunku południowo-zachodnim (ok. $230 \mathrm{~km}$ ) Woods Mountain (Montagne des Bois) i Willow Bunch (Bouquet de Saules). (6) Jeszcze dalej, w kierunku południowo-zachodnim Foremost Man w Maple Creek niedaleko Cypress Hills (Montagne des Cyprès). (7) Kaposvar dla Węgrów (ok. 300 km na wschód od Lebret), dalej misja przy Fort Ellice, trochę na północ Russell i Fort Pelly. (8) W kierunku południowo-wschodnim (ok. $150 \mathrm{~km}$ ) w Moose Mountain (Montagne de l'Orignal), Ocean Man, Pheasant Rump i White Bear ${ }^{43}$.

${ }^{39}$ Por. T. Ortolan, Cent ans d'Apostolat dans les deux Hémisphères, dz. cyt., t. 2, s. 171. Jako dom założona w 1884 r. (Personnel 1895, s. 55).

${ }^{40}$ Por. T. Ortolan, Cent ans d'Apostolat dans les deux Hémisphères, dz. cyt., t. 4, s. 104-105; Personnel 1899, s. 65.

${ }^{41}$ Początkowo jako misja pw. św. Floriana, a od 1887 r. pw. Najświętszego Serca (Sacré-Coeur). Por. T. Ortolan, Cent ans d'Apostolat dans les deux Hémisphères, dz. cyt., t. 4, s. 113 i 115.

${ }^{42}$ Por. tamże, s. 117.

${ }^{43}$ Co do każdej z tych stacji podawać można dalsze szczegóły. Przykładowo rezydencję w Lac Croche założono między rokiem 1895 a 1899, ale już wcześniej głoszono tam Ewangelię w czterech rezerwatach (P. Scharsch, Geschichte der Kongregation der Oblaten der Heiligsten und Unbeflecten Jungfrau Maria, Bd. 2, dz. cyt., s. 291). W okolicy powstało miasto Regina. Nie było go 
Pracę misjonarzy w tym regionie dokładnie przedstawia przełożony misji Qu'Appelle o. Magnan w liście z 25 stycznia 1889 r. do superiora generalne$\mathrm{go}^{44}$.

\section{Diecezja St-Albert}

W 1857 r. do pomocy biskupowi Taché został skierowany o. Grandin ${ }^{45}$, który w dwa lata później został wyświęcony na biskupa. Gdy w 1871 r. została erygowana diecezja St-Albert (wydzielona z części diecezji St-Boniface), bp Grandin stanął na jej czele ${ }^{46}$. W roku 1891 podzielono ją, a z jej północno-wschodniej części utworzono wikariat apostolski Saskatchewan. Po podziale diecezja St-Albert zawierała basen górnych ramion rzeki Saskatchewan oraz prerie zachodniej Kanady.

Na początku 1857 r., po wstąpieniu do oblatów ks. A. Lacombe'a, obsługiwane przez niego olbrzymie obszary dostały się pod opiekę tego zgromadzenia. Znajdowały się na nich wszystkie stacje misyjne wokół Jeziora Świętej Anny, wokół Małego Jeziora Niewolniczego, a nawet na skrawku ziemi nad Rzeką Pokoju (Peace River). Omawianie tego terenu rozpoczniemy od północy, dzieląc go na pięć części. Lac la Biche było najbardziej na północ wysuniętą misją tej diecezji (Red Deer Lake). Pierwszy raz odwiedził te tereny diecezjalny kapłan, ks. Thibault, w roku 1845 . W 1848 r. założyli tam rezydencję oblaci. W 1869 r. diecezja St-Albert oddała tę rezydencję wikariatowi Mackenzie, aby mu ułatwić administrację i zaopatrzenie ${ }^{47}$.

jeszcze w 1882 r., gdy przybył tam o. Hugonard (T. Ortolan, Cent ans d'Apostolat dans les deux Hémisphères, dz. cyt., t. 4, s. 153), a już w 1888 r. zostało wraz z Lebert i Broadview oddane kapłanom diecezjalnym (P. Scharsch, Geschichte der Kongregation der Oblaten der Heiligsten und Unbeflecten Jungfrau Maria, Bd. 2, dz. cyt., s. 291). Regina diecezją od 1910 r., metropolią od 1915 r. (Annuario, s. 539). Rezydencję w Lestock otwarto w 1896 r. (Personnel 1899, s. 65). Misję Kaposvar założono w 1890 r., stała się rezydencją między rokiem 1895 a 1899 (Personnel 1899, s. 66). Rezydencja Fort Elice założona została przed 1895 r. (Personnel 1895, s. 58), a rezydencja Fort Pelly przed 1899 r. (Personnel 1899, s. 66).

${ }^{44}$ Por. „Missions” 27 (1889), s. 133-164. Na stronach 162-163 podany jest dokładny wykaz punktów misyjnych dystryktu Qu'Appelle. Wymienia on m.in. 25 punktów wśród Indian.

${ }^{45}$ Por. F.J. Dolphin, Biskup Indian Zachodniej Kanady: Vitalis Justin Grandin (1829-1902), Katowice 1993.

${ }^{46}$ Por. Dom P. Benoît, Vie de Mgr Taché, dz. cyt., t. 1, s. 264 i 405 oraz t. 2, s. 144; A. Baran, Provision for the Canadian Church..., dz. cyt., s. 756, mówi o erekcji diecezji w 1890 r.

${ }^{47}$ O. Albert Lacombe jest postacią, która odegrała ważną rolę w XIX-wiecznej Kanadzie. Wspomina o nim nawet L.J. Rogier, Historia Kościoła, t. 5: 1848 do czasów współczesnych, Warszawa 1985, s. 183. W języku polskim ukazała się praca: J. Schulte, Wielki wódz prerii - Albert Lacombe, Warszawa 1988. Por. ponadto: E.J.M. Grouard, Souvenir de mes soixante ans d'apostolat dans l'Athabaska-Mackenzie, Lyon 1923, s. 179; Personnel 1895, s. 63; D. Levasseur, Histoire des Missionnaires Oblats de Marie Immaculée, dz. cyt., t. 1, s. 240. Por. Dom P. Benoît, Vie de Mgr Taché, dz. cyt., t. 2, s. 146. 
Drugim obszarem był dystrykt St-Albert. Najstarszą misją nie tylko tego dystryktu, ale i całej diecezji, była misja Lac Ste-Anne założona w roku 1842 przez kapłanów bp. Provenchera. W latach 1844-1853 była przez nich czasowo odwiedzana. W 1853 r. przyszli tu oblaci i dwa lata później założyli stałą rezydencję. Z czasem jednak najważniejszym domem w okolicy została rezydencja w St-Albert. Pierwszy raz przybyli tam bp Taché i o. Lacombe w roku 1860. W 1863 r. założono tu dom. W roku 1868 miejscowość ta stała się rezydencją biskupią, a od 1871 r. jest stolicą diecezji. Ważniejszymi stacjami misyjnymi podlegającymi domowi w St-Albert były: St-Emerentiana, St-Peter, St-Alexandre, Lac Lanon, Rivière-qui-Barre, Stony Plain oraz znajdujący się ponad $300 \mathrm{~km}$ na zachód Fort Jasper w Górach Skalistych ${ }^{48}$.

Trzecim godnym wyróżnienia obszarem był dystrykt Edmonton. Rezydencja w Edmonton została założona w 1858 r., ale z powodu nieprzychylnej postawy zwierzchnictwa fortu (wtedy był to Fort des Praires) misjonarze mogli się tam osiedlić dopiero w roku 1881. Do domu w Edmonton należała troska o stacje misyjne: Edmonton-North, Edmonton-Süd, Wetaskiwin, Leduc, Spruce-Grove, Fort Saskatchewan, Edna, Morinville, Hobbema, Stony Plain i Winterburn. Na tym terenie, podobnie jak i na sąsiednich, oblaci zajmowali się szczególnie Krysami (Cree) prerii, mało znającymi Ewangelię, choć również obsługiwali stacje misyjne założone w skupiskach białych i Metysów, zwłaszcza w obozach łowców bizonów na wielkich preriach ${ }^{49}$.

Dystrykt Lac la Selle (Saddle Lake) - na wschód od dystryktu Edmonton - obejmował całą sieć misji wokół tego jeziora. Najbardziej wysuniętym na północny zachód jego punktem był Beaver Lake (Lac Castor). Bliżej Lac la Selle była położona misja St-Paul des Cris założona w roku 1865, a w $1873 \mathrm{r}$. opuszczona. Na zachód od Lac la Selle leżała misja St-Paul des Métis nad Lac des Oeufs (Egg Lake) założona w roku 1897. W 1879 r. na północnym zachodzie ufundowano misję nad Lac Froid (Cold Lake). Na południowym zachodzie znajdował się Fort Pitt. Teren ten odwiedzano już od 1854 r., ale rezydencję założono tam dopiero w roku 1875. Misji tej podlegały stacje: Lac d'Oignon (Onion Lake), Lac la Grenouille (Frog Lake), Lac En-Long i Lac des Roches. W roku 1895 założono też rezydencję w Delmas ${ }^{50}$.

${ }^{48}$ Por. Personnel 1895, s. 59-60; Personnel 1899, s. 68; T. Ortolan, Cent ans d'Apostolat dans les deux Hémisphères, dz. cyt., t. 4, s. 161; Rapport du vicariat de Saint-Albert, „Missions” 36 (1898), s. 202-230; T. Ortolan, Cent ans d'Apostolat dans les deux Hémisphères, dz. cyt., t. 4, s. 162; Rapport sur le vicariat de Saint-Albert, „Missions” 31 (1893), s. 353 mówi o zamknięciu placówki nad Lac Lanon.

${ }^{49}$ Por. T. Ortolan, Cent ans d'Apostolat dans les deux Hémisphères, dz. cyt., t. 4, s. 160; P. Scharsch, Geschichte der Kongregation der Oblaten der Heiligsten und Unbeflecten Jungfrau Maria, Bd. 2, dz. cyt., s. 733-735; D. Levasseur, Histoire des Missionnaires Oblats de Marie Immaculée, dz. cyt., t. 1, s. 136.

${ }^{50}$ Por. T. Ortolan, Cent ans d'Apostolat dans les deux Hémisphères, dz. cyt., t. 4, s. 162-163; D. Levasseur, Histoire des Missionnaires Oblats de Marie Immaculée, dz. cyt., t. 1, s. 240. 
Piątym, ważnym dla oblatów obszarem był dy strykt Calgary - zaczęto go penetrować około roku 1863, a pierwszą rezydencję założono w samym mieście Calgary w roku $1874^{51}$. Oblaci głosili tu Ewangelię nie tylko wśród Czarnych Stóp, lecz również wśród Assiniboines.

Powołując się na ustalenia innych historyków, Levasseur twierdzi, że założenie i rozwój diecezji Calgary zawdzięczamy energii oraz wierze oblatów. Powołali oni do życia parafie w samym Calgary, w licznych centrach wzdłuż kolei, w regionach górniczych i w dolinie Bow River (Rivière de l'Arc). W latach 1865-1871 na całym tym terytorium prowadzili misje wędrowne oraz głosili Ewangelię w rezerwatach indiańskich ${ }^{52}$. W 1874 r. została założona rezydencja-baza dla misjonarzy w mieście Calgary. Misjonarze ci udawali się aż do Gór Skalistych. Z ważniejszych odwiedzanych przez nich stacji misyjnych wypada wspomnieć: Maple Creek, Cochrane, Morley, Anthracite, Banff, Laggan, Parc-National. Ponadto w okolicy Calgary powstawały nowe rezydencje: Macleod, Pincher Creek, Lethbridge ${ }^{53}$.

Już od roku 1865 misjonarze zaczęli odwiedzać Czarne Stopy ${ }^{54}$. Z czasem założyli rezydencje w rezerwatach: wśród Piéganes (w dzisiejszym Brocket) w 1881 r., wśród Czarnych Stóp (dzisiejsze Cluny) w 1883 r. i wśród Gensdu-Sang (dzisiejsze Cardson) w 1889 r. W 1881 r. w Dunbow założyli szkołę przemysłową dla chłopców indiańskich ${ }^{55}$. W roku 1898 oblaci pracowali w 22 parafiach i misjach diecezji Calgary, obsługując ponadto 24 stacje misyjne. W czterech parafiach pracowali księża diecezjalni ${ }^{56}$.

\section{Wikariat apostolski Saskatchewan}

Dnia 12 marca 1891 r. abp Montrealu otrzymał brewe papieskie dzielące dotychczasową diecezję St-Albert i erygujące jej północnowschodnią część w wikariat apostolski Saskatchewan. Na pasterza tego wikariatu wybrany zo-

${ }^{51}$ Por. Personnel 1895, s. 61; D. Levasseur, Histoire des Missionnaires Oblats de Marie Immaculée, dz. cyt., t. 1, s. 242, mówi o roku 1873. Pierwsze wizyty na tym terenie wg Levasseura miały miejsce w 1863 r., wg Ortolana (Cent ans d'Apostolat dans les deux Hémisphères, dz. cyt., t. 4, s. 167) w 1865 r.

52 Por. D. Levasseur, Histoire des Missionnaires Oblats de Marie Immaculée. Essai de synthèse, t. 2: 1898-1985, Montreal 1983-1986, s. 129. Calgary stało się stolicą diecezji w 1912 r. (Annuario, s. 122).

${ }^{53} \mathrm{~W}$ Banff oblaci prowadzili parafię od 1888 r. (por. D. Levasseur, Histoire des Missionnaires Oblats de Marie Immaculée, dz. cyt., t. 2, s. 129). Por. ponadto T. Ortolan, Cent ans d'Apostolat dans les deux Hémisphères, dz. cyt., t. 4, s. 178; Rapport sur le vicariat de Saint-Albert, „Missions” 31 (1893), s. 352.

${ }^{54}$ Por. T. Ortolan, Cent ans d'Apostolat dans les deux Hémisphères, dz. cyt., t. 4, s. 167.

${ }^{55}$ Por. État général du Personnel de la Congrégation des Missionnaires Oblats de Marie Immculée - no 6 - décembre 1904 [dalej cyt. jako: Personnel 1904], Bar-Le-Duc 1905, s. 59 (wszystkie cztery placówki).

${ }^{56}$ Por. Rapport du vicariat de Saint-Albert, „Missions” 36 (1898), s. 199-202. 
stał o. Pascal ${ }^{57}$. Przy omawianiu tego terenu trzeba się znów cofnąć w czasie, gdyż najstarsza misja pochodzi z 1846 r. Aby chronologicznie przedstawić rozwój omawianego wikariatu, teren ten ukażemy, zaczynając od północy i uwzględniając podział na poszczególne dystrykty.

Geneza dystryktu Ile-à-la-Crosse sięga roku 1846, kiedy to ks. Lafleche i o. Taché założyli misję w Ile-à-la-Crosse (w skrócie Ile). Odtąd misja ta stała się bazą pracy wśród wielkiej liczby Krysów (Cree) i Montanezów (Montagnais). $Z$ tej misji biorą swe początki wszystkie inne misje tego obszaru. Od roku 1854 ojcowie z Ile odwiedzali licznych Montanezów i Metysów gromadzących się wiosną i jesienią nad Grand Portage la Loche. Bliżej Ile misjonarze założyli stację misyjną nad Lac Canot. Odwiedzali także leżące na południowy wschód od niego Lac la Plonge. O misji nad tym jeziorem wspomina Duchaussois. Na południe od Lac la Plonge rozlewa się Green Lake (Lac Vert). Tutaj oblaci głosili Ewangelię już od roku 1847. Rezydencję założono tam jednak dopiero w roku 1868 . Wyruszano z niej do rezerwatów nad Lac Poule d'eau i Lac la Prairie. W roku 1890 otwarto tam także misję dla Metysów francusko-kryskich ${ }^{58}$. O rozległym promieniowaniu misji Ile-à-la-Crosse może świadczyć to, że o. Gasté przebywający wśród Inuitów w Doobant Lake (1000 km na północ) spotkał ludzi z tej misji ${ }^{59}$.

Drugim obszarem, który warto wyróżnić, był dystrykt Cumberland. Od 1847 r. oblaci z Ile docierali nad Jezioro Reniferowe (Reindeer Lake, Lac Caribou, Lac du Renne). Założyli tam misję wśród Montanezów na miejscu dzisiejszego Brochet $^{60}$. W 1861 r. powstała tam rezydencja. Na południe od niej znajduje się Lac Pélican. W miejscu zwanym Détroit du Pélican (Pelican Narrows) już w 1875 r., przez dwa miesiące, głosił Ewangelię Krysom o. Blanchet. Od 1878 r. misjonarz przebywał tam już na stałe. Inne centrum ewangelizacji utworzono w Pakitawagan (Pukatawagan). Najpierw docierano w to miejsce z Lac Pélican, a w 1886 r. założono tam stałą rezydencję. Ponadto nad brzegami Lac Cumberland ufundowano Cumberland House w roku 1877. Misjonarze z Cumberland oraz Lac Pélican kładli podwaliny wspólnot chrześcijańskich w Le Pas, Norway House (nad Lac Winnipeg), Lac la Corne i aż po Fort Nelson nad Zatoką Hudsona ${ }^{61}$.

${ }^{57}$ Por. Dom P. Benoit, Vie de Mgr Taché, dz. cyt., vol. 2, s. 634-635.

${ }^{58}$ Por. J.É. Champagne, Nos premières missions, dz. cyt., s. 157. Stały misjonarz-rezydent był tam od roku 1895 (D. Levasseur, Histoire des Missionnaires Oblats de Marie Immaculée, dz. cyt., t. 2, s. 170); T. Ortolan, Cent ans d'Apostolat dans les deux Hémisphères, dz. cyt., t. 4, s. 125, 131; P. Duchaussois, Wśród lodów polarnych u Indjan [sic!-WK] i Eskimosów, tłum. J. Korzeniowska, Krobia 1931, s. 335; Rapport sur le vicariat de la Saskatchewan, „Missions” 31 (1893), s. 418.

${ }^{59}$ Por. C. Choque, L'Église et les Inuit, VOL 47 (1988), s. 25; D. Levasseur, Histoire des Missionnaires Oblats de Marie Immaculée, dz. cyt., t. 1, s. 239.

${ }^{60}$ Por. D. Levasseur, Histoire des Missionnaires Oblats de Marie Immaculée, dz. cyt., t. 1, s. 239.

${ }^{61}$ Por. Personnel 1895, s. 76; T. Ortolan, Cent ans d'Apostolat dans les deux Hémisphères, dz. cyt., t. 4, s. 139-140; P. Scharsch, Geschichte der Kongregation der Oblaten der Heiligsten und 
W roku 1879 o. Leduc kupił w Prince Albert (w dystrykcie Prince A1bert) teren pod kościół, a w cztery lata później otworzono rezydencję ${ }^{62}$. Od roku 1890 miejscowość ta była siedzibą biskupią. Niedaleko na południe od niej leżała rezydencja misyjna St-Laurent (Grandin) ${ }^{63}$. Odwiedzano stamtąd pobliski Fort Carlton ${ }^{64}$. Na południowy wschód od St-Laurent położone były St-Louis-de-Langevin i Domremy. W 1885 r. St-Louis-de-Langevin stało się aglomeracją. Rezydencję założono tam już przed rokiem $1893^{65}$. Tamtejsi misjonarze głosili Ewangelię w okolicy, w promieniu ponad $100 \mathrm{~km}$ w: Stony Creek, Fish Creek (Anse aux Poissons), nad Rivière Carotte, w Fort Lacorne, Montagne des Bouleaux i innych mniejszych miejscowościach ${ }^{66}$.

Jeszcze dalej na południe położone było Batoche. Pierwszy raz dotarł tam o. Leduc w 1867 r., a w 1881 r. założono tam rezydencję ${ }^{67}$. Nieco na zachód od dwóch powyższych dystryktów (Cumberland i Prince Albert) leżało Duck Lake (Lac Canard). Pierwszy raz przybyli tu oblaci w 1868 r. i odtąd odwiedzali je regularnie, a w 1877 r. w miejscu tym założyli rezydencję ${ }^{68}$. Misjonarze z wyżej wymienionych miejscowości odwiedzali również szybko rosnące Saskatoon, położone w kierunku południowym ${ }^{69}$. Od 1878 r. oblaci głosili Ewangelię w rezerwacie Krysów nad Lac du Marais (Maskeg Lake). W tymże roku powstała tam rezydencja, która na ogół znana jest jako N.-D. de Pontmain. Tamtejsi misjonarze opiekowali się również mieszkańcami okolicznych rezerwatów: Snake Plain, Sandy Lake, Stell River, Devil's Lake, Sauteaux de la Rivière Serpent ${ }^{70}$.

Unbeflecten Jungfrau Maria, Bd. 2, s. 728-729; D. Levasseur, Histoire des Missionnaires Oblats de Marie Immaculée, dz. cyt., t. 1, dz. cyt., s. 240;

${ }^{62}$ Por. Personnel 1895, s. 73; T. Ortolan, Cent ans d'Apostolat dans les deux Hémisphères, dz. cyt., t. 4, s. 144.

${ }^{63}$ Mówi o niej np. T. Ortolan, Cent ans d'Apostolat dans les deux Hémisphères, dz. cyt., t. 4, s. 148. Wspomina ją jeszcze w 1893 r. Rapport sur le vicariat de la Saskatchewan, „Missions” 31 (1893), s. 413. O jej zamknięciu wspomina P. Scharsch, Geschichte der Kongregation der Oblaten der Heiligsten und Unbeflecten Jungfrau Maria, Bd. 2, dz. cyt., s. 724. Nie zna jej już Personnel 1895.

${ }^{64}$ Por. T. Ortolan, Cent ans d'Apostolat dans les deux Hémisphères, dz. cyt., t. 4, s. 148 i 151.

${ }^{65}$ Wymienia ją już Rapport sur le vicariat de la Saskatchewan, „Missions” 31 (1893), s. 413.

${ }^{66}$ Por. T. Ortolan, Cent ans d'Apostolat dans les deux Hémisphères, dz. cyt., t. 4, s. 152.

${ }^{67}$ Por. tamże; Personnel 1895, s. 74.

${ }^{68}$ Por. T. Ortolan, Cent ans d'Apostolat dans les deux Hémisphères, dz. cyt., t. 4, s. 150, podaje ją jako rezydencję pw. Sacré-Coeur de Jésus. Personnel 1895, s. 74 i Personnel 1899, s. 84 jako SS. Coeurs. Personnel 1904, s. 68 jako Saint-Coeur de Marie.

${ }^{69}$ Por. P. Scharsch, Geschichte der Kongregation der Oblaten der Heiligsten und Unbeflecten Jungfrau Maria, Bd. 2, dz. cyt., s. 724. Rezydencji Saskatoon nie zna jeszcze Personnel 1899, ale jest już w Personnel 1904 (s. 69). W 1933 r. została erygowana diec. Saskatoon (Annuario, s. 609).

${ }^{70}$ Por. T. Ortolan, Cent ans d'Apostolat dans les deux Hémisphères, dz. cyt., t. 4, s. 151; Personnel 1895, s. 74; Rapport du vicariat de la Saskatchewan, „Missions” 36 (1898), s. 164, wymienia ponadto odwiedzane punkty Pologne, Lac Esturgeon i Rivière Coquille. 
O objęciu działalnością dystryktu Battleford myślano już wcześniej, ale pierwszy przybył tam o. Lestanc dopiero w roku 1877, aby założyć rezydencję. Misjonarze z Battleford odwiedzali rezerwaty: Thunderchild, Littre Pine, Sweet Grass, Poundmaker i Moosomin ${ }^{71}$.

\section{Wikariat apostolski Athabaska-Mackenzie}

Misjonarze dystryktów Athabaska i Mackenzie byli bardzo oddaleni i odizolowani od St-Boniface. Zdając sobie sprawę ze znaczenia swojej posługi, prosili o biskupa, który by zamieszkał razem z nimi i mógł bezpośrednio kierować ich pracą. Na prośbę bp. Taché Stolica Apostolska erygowała 13 maja 1862 r. wikariat apostolski Athabaska-Mackenzie i powierzyła go biskupowi Faraud $\mathrm{OMI}^{72}$. Misjonarze, obecni na tym terenie od roku 1847, dotarli wkrótce do wszystkich mieszkających tam szczepów indiańskich i stopniowo, wraz ze wzrostem liczebnym, intensyfikowali swoją działalność. Najstarszą misją dystryktu A thabaska była misja Nativité założona już w roku 1848 przez późniejszego bp. Taché w Fort Chipewyan ${ }^{73}$. Były z nią związane wszystkie rezydencje i cała praca misyjna. W 1853 r. o. Grollier założył misję na wschodnim krańcu jeziora Athabaska zwanym Fond-du-Lac. Wracał tam w latach 1854 i $1855^{74}$.

Wiele stacji misyjnych leżało nad Rzeką Pokoju. Pierwsza z nich - w Fort Vermillon - była odwiedzana przez oblatów od 1858 r. (wcześniej, bo już od 1846 r. przez księży diecezjalnych), od roku 1868 rezydowali tam misjonarze $^{75}$. Głosili oni Ewangelię w okolicy, zwłaszcza na północ od misji, udając się aż po Upper Hay River, Hay Lakes czy sam Fort Nelsona ${ }^{76}$. Inną większą misję nad Rzeką Pokoju założono w Fort Dunvégan. Ojciec Faraud głosił tam Ewangelię już w roku 1849, a rezydencję założono w roku $1868^{77}$. Misjona-

${ }^{71}$ Por. T. Ortolan, Cent ans d'Apostolat dans les deux Hémisphères, dz. cyt., t. 4, s. 145-146; Personnel 1895, s. 75. Rezydencję w Thunderchild wymienia Personnel 1904, s. 69, bez podania roku założenia. O rezydującym w Poundmaker misjonarzu wspomina P. Scharsch, Geschichte der Kongregation der Oblaten der Heiligsten und Unbeflecten Jungfrau Maria, Bd. 2, dz. cyt., s. 125. Por. też Rapport sur le vicariat de la Saskatchewan, „Missions” 31 (1893), s. 417.

72 Por. D. Levasseur, Histoire des Missionnaires Oblats de Marie Immaculée, dz. cyt., t. 1, s. 233; Dom P. Benoît, Vie de Mgr Taché, dz. cyt., vol. 1, s. 464.

${ }^{73}$ Por. J.É. Champagne, Nos premières missions, dz. cyt., s. 160; Personnel 1895, s. 64.

${ }^{74}$ Por. Personnel 1895, s. 65; T. Ortolan, Cent ans d'Apostolat dans les deux Hémisphères, dz. cyt., t. 2, s. 187-188.

${ }^{75}$ Por. Personnel 1895, s. 66; D. Levasseur, Histoire des Missionnaires Oblats de Marie Immaculée, dz. cyt., t. 2, s. 149.

${ }_{76}$ Por. tamże. Wg Rapport sur le vicariat d'Athabaska-Mackenzie, „Missions” 31 (1893), s. 372, Fort Vermillon był siedzibą anglikańskiego biskupa Athabaski.

${ }^{77}$ Por. Personnel 1895, s. 66; D. Levasseur, Histoire des Missionnaires Oblats de Marie Immaculée, dz. cyt., t. 1, s. 134 i t. 2, s. 148. 
rze $\mathrm{z}$ tego domu zapewniali opiekę nad stacjami pomocniczymi nad Rivière Boucane (Rivière Enfumée, Smoky River), Grande Prairie, Fort St-John i Fort Hudson's Hope (Portage de la Montagne) ${ }^{78}$.

Kolejną misją, która promieniowała na całą okolicę, była misja pw. św. Bernarda, leżąca nad Małym Jeziorem Niewolniczym w dzisiejszym Grouard. Pierwszymi oblatami, którzy ją odwiedzali, byli oo. Lacombe i Rémas (ten drugi od 1864). Rezydencję założono w latach siedemdziesiątych lub osiemdziesiątych XX w. ${ }^{79}$ Obsługiwano z niej liczne placówki pomocnicze nad Lac des Esturgeons, Lac du Poisson Blanc, Lac Wabasca, Lac la Truite, Rivière du Coeur i na wschodnim wybrzeżu Małego Jeziora Niewolniczego (pw. St-Joachim). Z mniejszych można wymienić Athabasca Landing, Lac de l'Ours, Lac de l'Orignal oraz Lac Kitow ${ }^{80}$. Na samym skraju dystryktu znajdowała się misja założona w Fort Smith. Ojciec Faraud przechodził tamtędy w drodze nad Wielkie Jezioro Niewolnicze już w roku 1852. Wkrótce założono tu misję, którą obsługiwali misjonarze z Nativité ${ }^{81}$.

Pierwszą bazą misyjną w dystrykcie Mackenzie stała się misja przy Fort Resolution nad Wielkim Jeziorem Niewolniczym. Jej zręby założył w roku 1856 o. Faraud. Był tu już nawet z krótką wizytą w roku 1852, ale właściwa rezydencja została założona $\mathrm{w}$ roku $1858^{82}$. Odtąd regularnie odwiedzano z niej różne miejscowości. Nad brzegami jeziora leżały także stacje misyjne St-Vincent de Paul (w głębokiej zatoce na wschodzie jeziora) oraz Ste-Anne (u ujścia Hay River do jeziora, na zachód od Fort Resolution) ${ }^{83}$. Jeszcze

${ }^{78}$ Por. T. Ortolan, Cent ans d'Apostolat dans les deux Hémisphères, dz. cyt., t. 4, s. 234. Dwie ostatnie stacje powyżej Fortu Dunvégan.

${ }^{79}$ Por. D. Levasseur, Histoire des Missionnaires Oblats de Marie Immaculée, dz. cyt., t. 2, s. 147. Personele z lat 1895-1904 znają tę rezydencję, ale nie podają daty jej założenia. Wg T. Ortolan, Cent ans d'Apostolat dans les deux Hémisphères, dz. cyt., t. 4, s. 237, było to w roku 1871. Wg D. Levasseur, Histoire des Missionnaires Oblats de Marie Immaculée, dz. cyt., t. 2, s. 147, w 1872.

${ }^{80}$ Por. T. Ortolan, Cent ans d'Apostolat dans les deux Hémisphères, dz. cyt., t. 4, s. 239-240; É.J.M. Grouard, Souvenir de mes soixante ans d'apostolat, dz. cyt., s. 280-281; Rapport sur le vicariat d'Athabaska-Mackenzie, „Missions” 31 (1893), s. 367; Rapport du vicariat d'Athabaska-Mackenzie, „Missions” 36 (1898), s. 185. Stację St-Martin nad Lac Wabasca założył bp Grouard w 1895 r. (P. Duchaussois, Wśród lodów polarnych..., dz. cyt., s. 51). Rezydencją była od 1897 r. (D. Levasseur, Histoire des Missionnaires Oblats de Marie Immaculée, dz. cyt., t. 2, s. 148) lub 1899 r. (P. Scharsch, Geschichte der Kongregation der Oblaten der Heiligsten und Unbeflecten Jungfrau Maria, Bd. 2, dz. cyt., s. 749). Personnel 1899 i Personnel 1904 nie podają daty założenia rezydencji.

${ }^{81}$ Por. T. Ortolan, Cent ans d'Apostolat dans les deux Hémisphères, dz. cyt., t. 2, s. 211-212 i t. 4, s. 241-242.

${ }^{82}$ Por. Personnel 1895, s. 65; T. Ortolan, Cent ans d'Apostolat dans les deux Hémisphères, dz. cyt., t. 2, s. 214 i t. 4, s. 244.

${ }^{83}$ Por. T. Ortolan, Cent ans d'Apostolat dans les deux Hémisphères, dz. cyt., t. 4, s. 249. O. Gascon założył misję Ste-Anne w 1867 r., ale od roku 1878 zaniechano jej odwiedzania aż do roku 1900 (P. Duchaussois, Wśród lodów polarnych ..., dz. cyt., s. 287-288). 
dalej na zachód, na Grande Ile (Big Island), w 1858 r. o. Grollier założył stację misyjną w Forcie Wrigley. W następnych latach zachodzili tam misjonarze, lecz nie został on stałą rezydencją ${ }^{84}$. W marcu 1859 r. o. Grollier pierwszy raz odwiedził Fort Rae, a w 1873 r. założono tam rezydencję ${ }^{85}$.

W roku 1860 w szczerym polu oblaci założyli misję Providence. Dopiero później wybudowany tam został Fort Providence ${ }^{86}$.

W miejscu, gdzie do Liard River wpływa Petitot River (Black River, Rivière Noire), wznosi się Fort Liard. Ojciec Gascon przybył doń pierwszy raz w roku 1858, a w dwa lata później założono tam rezydencję ${ }^{87}$. Misjonarze z Fort Liard odwiedzali również Fort Halket (pierwszy raz w 1861). Z czasem placówka Fort Halket została zastąpiona stacją misyjną w większym Fort Nelson ${ }^{88}$. Jeszcze wyżej, w górach, bliżej źródeł Liard River i Fort Nelson River wznosi się Fort Nelson. W latach 1868 i 1869 odwiedzał go o. Grouard, a potem inni misjonarze ${ }^{89}$. Posuwając się na północ $\mathrm{z}$ biegiem Mackenzie River, docieramy do Fort Simpson. Pierwszy raz zawitał tam o. Grollier w 1858 r. ${ }^{90}$, a stałą rezydencję otwarto tu w roku $1894^{91}$. Dalej, idąc z biegiem rzeki, na wysokości Wielkiego Jeziora Niedźwiedziego natrafiamy na Fort Norman. Już w 1859 r. i w następnych latach krótko przebywał tutaj o. Grollier. W 1866 r. zamieszkał tu we własnoręcznie wybudowanym domu o. Petitot (do roku 1872) $)^{92}$. Jeszcze dalej na północ, pod samym kręgiem polarnym leży Good Hope. Rezydencja misjonarzy została tam założona w roku $1858^{93}$. Nad brzegami Morza Beauforta, a ściślej nad deltą Mackenzie, wznosi się Fort McPherson. Pierwszy raz zawitał tam o. Grollier w roku 1860. Ponadto w latach dziewięćdziesiątych na

${ }^{84}$ Por. T. Ortolan, Cent ans d'Apostolat dans les deux Hémisphères, dz. cyt., t. 2, s. 218 i t. 4, s. 268.

${ }^{85}$ Por. Personnel 1895, s. 67; T. Ortolan, Cent ans d'Apostolat dans les deux Hémisphères, dz. cyt., t. 4, s. 237; P. Duchaussois, Wśród lodów polarnych ..., dz. cyt., s. 248.

${ }^{86}$ Por. Personnel 1895, s. 66; T. Ortolan, Cent ans d'Apostolat dans les deux Hémisphères, dz. cyt., t. 4, s. 255-256.

${ }^{87}$ Por. D. Levasseur, Histoire des Missionnaires Oblats de Marie Immaculée, dz. cyt., t. 1, s. 135; Personnel 1895, s. 67; T. Ortolan, Cent ans d'Apostolat dans les deux Hémisphères, dz. cyt., t. 4, s. 265. Według Levasseura o. Gascon przybył w roku 1859.

${ }^{88}$ Por. T. Ortolan, Cent ans d'Apostolat dans les deux Hémisphères, dz. cyt., t. 4, s. 266; P. Duchaussois, Wśród lodów polarnych..., dz. cyt., s. 282.

${ }^{89}$ Por. T. Ortolan, Cent ans d'Apostolat dans les deux Hémisphères, dz. cyt., t. 4, s. 267. O ojcu, późniejszym biskupie Grouard istnieje książka w języku polskim - H. Gstrein, Nie szczędzil trudu: misjonarze, którzy tworzyli historię: Emil Grouard 1840-1922. Apostoł z Athabaski, thum. J. Środulski, Warszawa 1994.

${ }^{90}$ Por. tamże, II, s. 220.

${ }^{91}$ Personele 1895-1904 nie podają daty założenia.

${ }^{92}$ Por. T. Ortolan, Cent ans d'Apostolat dans les deux Hémisphères, dz. cyt., t. 4, s. 246 i 270. Położony nad nieuregulowaną rzeką Fort Norman kilkakrotnie musiał się przenosić z miejsca na miejsce. O tych zmianach miejsca por. P. Duchaussois, Wśród lodów polarnych ..., dz. cyt., s. 293.

${ }^{93}$ Por. Personnel 1895, s. 68. 
wyspach Richard i Herschell pracowali oo. Giroux i Lefebvre. Misja istniała również w delcie Mackenzie przy Fort Peel's River ${ }^{94}$. W roku 1865 o. Petitot udał się do Fort Anderson nad Anderson River. Jednak rok później fort ten został opuszczony przez Towarzystwo Zatoki Hudsońskiej. Misjonarze skierowali się więc ku Eskimosom delty Mackenzie ${ }^{95}$.

$\mathrm{Na}$ wspomnienie zasługuje też próba ewangelizacji Alaski (omówiona zostanie w następnym rozdziale) oraz założenie misji na terytorium Jukonu nad rzeką Klondike. W 1896 r. odkryte zostały słynne złotodajne złoża w Jukonie, co wywołało prawdziwą , gorączkę złota”. Tylko w 1897 r. do Klondike napłynęło blisko 30 tys. poszukiwaczy ze Stanów Zjednoczonych. Łatwiej dostępne złoża wyczerpały się już w roku 1899. Biskup Grouard (wikariusz apostolski Athabaska-Mackenzie) zawarł porozumienie z jezuitami na Alasce, mocą którego w razie konieczności mieli oni jurysdykcję na jego terenie. Było im bowiem łatwiej dotrzeć nad Klondike niż oblatom znad Mackenzie. Faktycznie przybyli na te tereny w roku 1897. Biskup Grouard podziękował im za to, lecz kiedy wyraził swój zamiar wysłania tam oblatów, spotkał się ze sprzeciwem. Kuria Rzymska rozstrzygnęła sprawę na korzyść biskupa. Oblaci przybyli do Jukonu w roku 1898 i pracowali tam wraz z o. Judge SJ ${ }^{96}$.

\section{Diecezja New Westminster}

W 1846 r. traktat między Kanadą i Stanami Zjednoczonymi podzielił Oregon wzdłuż 49 równoleżnika, pozostawiając jednak wyspę Vancouver w rękach brytyjskich. Dnia 24 lipca 1846 r. olbrzymi teren ówczesnego wikariatu apostolskiego Oregonu został podzielony na trzy diecezje. Biskupem części obejmującej wyspę Vancouver oraz kontynentalną Kolumbię Brytyjską został Modeste Demers ${ }^{97}$. Na prośbę biskupa przybyli tam oblaci. Pierwszy dom został otwarty w roku $1858 \mathrm{w}$ Esquimalt. Biskup miał wtedy do pomocy tylko dwóch kapłanów diecezjalnych ${ }^{98}$. Osiedliwszy się w Esquimalt, oblaci roz-

${ }^{94}$ Por. R. Bulliard, Misje na krańcu świata, Warszawa 1974, s. 204; C. Choque, L'Église et les Inuit, dz. cyt., s. 23; Rapport sur le vicariat d'Athabaska-Mackenzie, „Missions” 31 (1893), s. 380.

${ }_{95}$ Por. R. Bulliard, Misje na krańcu świata, dz. cyt., s. 204-205; C. Choque, L'Église et les Inuit, dz. cyt., s. 23.

${ }^{96}$ Por. P. Scharsch, Geschichte der Kongregation der Oblaten der Heiligsten und Unbeflecten Jungfrau Maria, Bd. 2, dz. cyt., s. 750; A.G. Morice, Histoire de l'Église catholique dans l'Ouest canadien du Lac Supérieur au Pacifique (1659-1905), t. 4, Winnipeg 1923, s. 347. W 1898 r. oblaci założyli rezydencję w Dawson. Wspomina o niej Personnel 1899 (s. 78). W 1900 r. założyli rezydencję w Whitehorse, ale nie wspomina o niej Personnel 1904.

${ }_{97}$ Por. D. Levasseur, Histoire des Missionnaires Oblats de Marie Immaculée, dz. cyt., t. 1, s. 140.

${ }^{98}$ W 1860 r. podczas choroby bp. Demersa miał zostać mianowany koadiutor. Biskupi kanadyjscy zaproponowali o. Trudeau, ale sprawa ta nie została sfinalizowana. Por. É. Lamirande, Le P.A. Trudeau O.M.I. et son refus de l'épiscopat. Pour l'histoire du diocèse de l'île Vancouver, VOL 
poczęli swą działalność na wyspie Vancouver. Początkowo zajmowali się okolicznymi białymi i Indianami, zwłaszcza w Victorii ${ }^{99}$. Tam też wybudowali kościół. W 1860 r. podjęto pierwszą wielką wyprawę misyjną wzdłuż wyspy ku północy przez Nanaimo do Fort Rupert, która trwała od kwietnia do czerwca. Nieco później wybrano się w podróż misyjną na zachodnie wybrzeże wyspy ${ }^{100}$. W 1863 r. na północy wyspy otwarto misję przy Fort Rupert, którą później przeniesiono, najpierw do Rarouais, a potem na wyspę Habledown. W 1864 r. dwóch misjonarzy udało się w niebezpieczną wyprawę do Wysp Archipelagu Królowej Karoliny (Queen Charlotte Islands) ${ }^{101}$. Ponieważ w Kolumbii Brytyjskiej kontynentalnej brakowało misjonarzy, w roku 1866 bp D’Herbomez OMI odwołał misjonarzy z rezydencji w Esquimalt oraz z kolegium w Victorii, a w 1874 r. z jałowej i po ludzku bezowocnej misji przy Fort Rupert ${ }^{102}$.

Od chwili przybycia oblatów na tereny kontynentalnej Kolumbii Brytyjskiej w 1858 r. założyciel starał się, aby Stolica Apostolska utworzyła tu wikariat powierzony zgromadzeniu. Starania te zakończyły się sukcesem w dwa lata po jego śmierci. W 1863 r. erygowany został wikariat apostolski Kolumbii Brytyjskiej kontynentalnej, do którego dołączono też Archipelag Królowej Karoliny ${ }^{103}$. Na mocy umowy z 1 września 1860 r. bp Demers powierzył oblatom ewangelizację Indian Kolumbii Brytyjskiej i troskę o białych rozproszonych w różnych okolicach. Jeszcze we wrześniu założono misję w New Westminster ${ }^{104}$. Tamtejsi misjonarze zajmowali się ewangelizacją okolicznych Indian i udawali się do Fortów Hope i Yale. W roku następnym otwarto dwie kaplice w New Westminster i jedną w Fort Hope. W tymże samym 1861 r. założono

44 (1985), s. 157-181; tenże, Les Oblats et la coadjutorerie de Mgr M. Demers. Ile de Vancouver (1861-1865), VOL 45 (1986), s. 371-393.

${ }^{99}$ Por. D. Levasseur, Histoire des Missionnaires Oblats de Marie Immaculée, dz. cyt., t. 1, s. 142; T. Ortolan, Cent ans d'Apostolat dans les deux Hémisphères, dz. cyt., t. 2, s. 329 i 4, s. 380. Dzisiejsza diecezja Victoria, sufragania archidiecezji Vancouver była w latach 1903-1908 archidiecezją (Annuario, s. 709).

${ }^{100}$ Por. D. Levasseur, Histoire des Missionnaires Oblats de Marie Immaculée, dz. cyt., t. 1, s. 142; T. Ortolan, Cent ans d'Apostolat dans les deux Hémisphères, dz. cyt., t. 2, s. 332 i t. 4, s. 383.

${ }^{101}$ Por. D. Levasseur, Histoire des Missionnaires Oblats de Marie Immaculée, dz. cyt., t. 1, s. 247; T. Ortolan, Cent ans d'Apostolat dans les deux Hémisphères, dz. cyt., t. 4, s. 387.

102 Por. D. Levasseur, Histoire des Missionnaires Oblats de Marie Immaculée, dz. cyt., t. 1, s. 249.

${ }^{103} \mathrm{~W}$ grudniu 1862 r. kard. Barnabò (Prefekt KRW) pytał o. Fabre (po śmierci założyciela przełożony generalny), czy oblaci nie objęliby prefektury apostolskiej Kolumbii Brytyjskiej. Po pozytywnej odpowiedzi Stolica Apostolska w grudniu 1863 r. zadecydowała o utworzeniu tam wikariatu apostolskiego, a na jego czele postawiła o. D’Herbomeza. Por. É. Lamirande, Mgr Louis d'Herbomez O.M.I., sa nomination comme vicaire apostolique de la Colombie-Britannique (1863), VOL 47 (1988), s. 47-49.

${ }^{104}$ Por. Personnel 1895, s. 69. Diecezja New Westminster erygowana została w 1890 r. (Annuario, s. 702). Dziś jest to archidiecezja Vancouver. 
rezydencję w Mission City ${ }^{105}$. Misjonarze udawali się na północny wschód aż do Maple Ridge (Colline aux Érables) nad brzegiem rzeki Fraser. Głosili też Ewangelię na zachód i północny zachód od New Westminster. Udawali się nad zatokę Burrard Inlet, gdzie pracowali wśród Squqmishów (w szkole dla dzieci indiańskich w North Vancouver) ${ }^{106}$. Dopiero później na południowym brzegu powstało dzisiejsze miasto Vancouver. W samym tylko roku 1861 misjonarze tego regionu odwiedzili ok. 12 tys. Indian ${ }^{107}$.

Pierwsza oblacka misja w Kolumbii Brytyjskiej została otwarta na wschód od rzeki Fraser. Już w 1860 r. założono misję nad jeziorem Okanagan w miejscu zwanym Anse au Sable ${ }^{108}$. Był to dobry punkt wypadowy do odwiedzania indiańskich szczepów okolicy. Misja ta została opuszczona przez oblatów w roku $1896^{109}$. W 1874 r. misjonarze założyli nową rezydencję wśród Indian Kootenays w Cranbrook. Służyła ona jako baza dla misjonarzy skrajnie południowej części wikariatu nad rzeką Kootenay ${ }^{110}$. Dużo nazw odwiedzanych miejscowości i szeroki obraz pracy oblatów z Cranbrook daje długoletni misjonarz tych terenów o. Coccola ${ }^{111}$. Już od roku 1862 oblaci głosili Dobrą Nowinę w dorzeczu rzeki Thompson. Odwiedzali tam szczepy indiańskie żyjące nad jeziorami Shoushouape (Shuswap), Adam oraz rzekami Bonaparte i Thompson (obydwa ramiona). W 1878 r. założono rezydencję w Kamloops ${ }^{112}$.

W roku 1861 o. Grandidier przybył w Góry Cariboo z New Westminster. Od tego czasu docierali tam także inni misjonarze. W roku 1867 udało się

${ }^{105}$ Por. Personnel 1895, s. 70. Z tej rezydencji ewangelizowano 7 szczepów Indian rozmieszczonych łącznie w 55 wioskach w promieniu 300 mil. Por. Rapport sur le vicariat de la Colombie-Britannique, „Missions” 31 (1893), s. 397.

106 Powstała między rokiem 1895 a 1899. Wymienia ją Personnel 1899 (s. 81). Ponadto w 1898 r. powstała inna rezydencja w Vancouver (Personnel 1899, s. 82). T. Ortolan, Cent ans d'Apostolat dans les deux Hémisphères, dz. cyt., t. 4, s. 443, mówi o pracy wśród Indian Sischelles i o szkole dla nich. Być może są to dwie nazwy tego samego szczepu.

${ }^{107}$ Por. A.G. Morice, Histoire de l'Église catholique, vol. 4, dz. cyt., s. 225. Więcej informacji o tej pracy podają: D. Levasseur, Histoire des Missionnaires Oblats de Marie Immaculée, dz. cyt., t. 1, s. 142-143. Por. T. Ortolan, Cent ans d'Apostolat dans les deux Hémisphères, dz. cyt., t. 4, s. 394-395.

${ }^{108}$ Por. Personnel 1895, s. 72.

109 Por. D. Levasseur, Histoire des Missionnaires Oblats de Marie Immaculée, dz. cyt., t. 1, s. 251. Odwiedzano 10 wiosek indiańskich w odległości do 150 mil od rezydencji. Por. Rapport sur le vicariat de la Colombie-Britannique, „Missions” 31 (1893), s. 409.

${ }^{110}$ Por. Personnel 1895, s. 80. Wcześniej przed oblatami, raz - dwa razy w roku odwiedzali te tereny jezuici. Por. L.J. D’Herbomez, Rapport sur le vicariat de la Colombie Britannique, „Missions" 17 (1879), s. 418-419. Misjonarze odwiedzali też trzy rezerwaty odległe o ponad 150 mil od rezydencji. Por. Rapport sur le vicariat de la Colombie-Britannique, „Missions” 31 (1893), s. 395.

${ }^{111}$ Por. N. Coccola, The „Memoirs” of Father Nicolas Coccola, O.M.I. 1883-1890. Pioneer Days in Okanagan and Kootenay, VOL 35 (1976), s. 28-49; tenże, Oblate Work in Southern British Columbia (1891-1905), VOL 39 (1980), s. 145-162.

112 Por. Personnel 1895, s. 71; T. Ortolan, Cent ans d'Apostolat dans les deux Hémisphères, dz. cyt., t. 4, s. 416-418. Dużo małych miejscowości podaje N. Coccola, The „,Memoirs ” of Father Nicolas Coccola..., dz. cyt., s. 22-28. 
założyć rezydencję nad William’s Lake (300 mil na północ od New Westminster). Misjonarze $\mathrm{z}$ tej rezydencji głosili Ewangelię Indianom rozproszonym $\mathrm{w}$ ponad 30 osadach $\mathrm{w}$ promieniu ponad $100 \mathrm{~km}$, przemierzając tym samym dzikie tereny z północy na południe i ze wschodu na zachód ${ }^{113}$. Z głównych stacji, które później stały się miastami, warto wymienić: Quesnel, Fort Alexandre, Soda Creek. Misjonarze przechodzili również na drugą stronę rzeki Fraser, w dolinę rzeki Chilcotim. Zadaniem misjonarzy tej placówki było niesienie pomocy Indianom i białym zatrudnionym w kopalniach $\mathrm{w}$ górach $\mathrm{Ca}$ riboo. Złotonośny region znajduje się między jeziorem Quesnel i północną krzywą Frasera. Jest to ok. $240 \mathrm{~km}$ od Jeziora Williamsa. W regionie tym została wybudowana kaplica w Richfield ${ }^{114}$.

Oblaci posuwali się jeszcze dalej na północ, aż nad jezioro Stuart i Tacla oraz do Fort Conelly. Wiosną 1873 r. została założona rezydencja nad Stuart's Lake niedaleko Fort St-James ${ }^{115}$. Stała się ona centrum ewangelizacji rozległego dystryktu rozciągającego się w promieniu ponad $200 \mathrm{~km}$, obejmującego 2-3 tys. Indian rozproszonych po olbrzymim terytorium (od Gór Skalistych po rzekę Skeena na północy). Z ważniejszych stacji misyjnych warto wspomnieć: Fort George ${ }^{116}$, Fort Fraser (dzisiejszy Vanderhoof) i miejsca wokół Babine Lake czy Fortu Mac Leod (nad jeziorem o tej samej nazwie) ${ }^{117}$.

Na podstawie tego, co zostało napisane, śmiało można powiedzieć, że cała zachodnia i północno-zachodnia Kanada była w XIX w. polem pracy misyjnej oblatów. Dla pełnego obrazu można dodać, że w końcu wspomnianego stulecia na tym terenie pracowało: 250 oblatów $^{118}, 52$ kapłanów diecezjalnych, 17 cystersów reformowanych z N.-D. de la Trappe w St-Norbert, kilku kanoników regularnych Niepokalanego Poczęcia, pięciu jezuitów, czterech Braci Maryi, 167 sióstr szarych z Montrealu, 45 Fidèles Compagnes de Jésus, 31 Sióstr Opatrzności, 28 Sióstr Świętych Imion Jezusa i Maryi, 19 zakonnic instytutu N.-D. du Refuge, 17 Sióstr Ste-Anne, 17 Sióstr Wniebowzięcia z Nicolet i dziewięć sióstr szarych z Nicolet ${ }^{119}$.

113 Por. Personnel 1895, s. 71; Rapport sur le vicariat de la Colombie-Britannique, „Missions” 31 (1893), s. 399-400.

114 Por. D. Levasseur, Histoire des Missionnaires Oblats de Marie Immaculée, dz. cyt., t. 1, s. 248; T. Ortolan, Cent ans d'Apostolat dans les deux Hémisphères, dz. cyt., t. 4, s. 420-426.

${ }^{115}$ Por. Personnel 1895, s. 71.

${ }^{116}$ Dziś Prince George.

117 Por. T. Ortolan, Cent ans d'Apostolat dans les deux Hémisphères, dz. cyt., t. 4, s. 433-436; D. Levasseur, Histoire des Missionnaires Oblats de Marie Immaculée, dz. cyt., t. 1, s. 248; Rapport sur le vicariat de la Colombie-Britannique, „Missions” 31 (1893), s. 403.

${ }^{118}$ Por. Personnel 1899, s. 62-86 (dane z roku 1899).

119 Por. D. Levasseur, Histoire des Missionnaires Oblats de Marie Immaculée, dz. cyt., t. 1, s. 251 (dane z roku 1898). 


\section{Stany Zjednoczone}

Do roku 1908 działalność Kościoła w Stanach Zjednoczonych podlegała Kongregacji Rozkrzewiania Wiary, jednak całego terenu Stanów drugiej połowy XIX w. nie można nazwać terenem misyjnym ${ }^{120}$. Działalność oblatów zaznaczyła się szczególnie na obszarze południowowschodnim. Już w roku 1880 ich praca obejmowała 10 diecezji $^{121}$. E. Hamon (jezuita) tak krótko charakteryzuje pole ich działalności: „W całej Nowej Anglii jest bardzo mało ośrodków kanadyjskich, jeśli w ogóle gdzieś takie są, gdzie by głos tych gorliwych Apostołów nie był słyszany"122. Nie można jednak tych terenów uznać za misyjne, więc nie będą tu omawiane. Ponadto oblaci podjęli pracę nad granicą Stanów Zjednoczonych z Meksykiem. O niespokojnej sytuacji w Meksyku może świadczyć fakt, że w latach 1821-1850 rząd zmieniał się 50 razy, i to przeważnie w wyniku zamachów wojskowych. Nic więc dziwnego, że odbijało się to także na sytuacji Kościoła w tym kraju. W 1861 r. zostali wypędzeni m.in. nuncjusz papieski, abp Garza, wielu biskupów i przedstawicieli dyplomatycznych ${ }^{123}$.

\section{Teksas}

Gdy bp Odin CM z Galveston (Teksas) przybył do Montrealu w poszukiwaniu kapłanów, swą pomoc ofiarował mu o. Telmon. Pierwsza grupa misjonarzy osiedliła się w Bronsville 5 grudnia 1849 r., natrafiono tam jednak na ogromne trudności. Najpierw oblaci odczuli wielką niechęć tamtejszych mieszkańców, potem doszły jeszcze wielkie kłopoty ze zdrowiem. Ostatecznie 22 stycznia 1851 r. ostatni oblat opuścił miasto. Po interwencji bp. Odina u założyciela oblaci wrócili na te tereny w następnym roku. Odtąd misja ta obejmowała posługę $\mathrm{w}$ mieście Bronsville i okolicznych ranczach oraz misje meksykańskie. W roku 1867 otwarto rezydencję w Romie ${ }^{124}$. Misjonarze teksańscy wnikali powoli w Meksyk, a kilku z nich osiedliło się nawet w $1858 \mathrm{r}$. przy małym sanktuarium N.-D. du Refuge w Agualeguas, skąd pomagali w pa-

${ }^{120}$ Por. L.J. Rogier i in. (red.), Historia Kościoła, t. 4: 1715-1848, Warszawa 1985, s. 147; A. Seumois, Problem terytorialnej reorganizacji Kongregacji Rozkrzewiania Wiary, w: Kościót na drodze spotkania z trzecim światem, red. B. Gielata, F. Zapłata, Warszawa 1971, s. 27.

${ }_{121}$ Por. D. Levasseur, Histoire des Missionnaires Oblats de Marie Immaculée, dz. cyt., t. 1, s. 211.

${ }^{122}$ Por. E. Hamon, Les Canadiens-français de la Nouvelle-Angletterre, Québec 1891, s. 367.

${ }^{123}$ Por. Krótka historia Meksyku, thum. S. Szczurkowska, Warszawa 1986, s. 129, 301. Szerzej o historii Meksyku w tym czasie por. tamże, s. 96-158.

${ }^{124}$ Szerzej o tej pierwszej próbie osiedlenia się por. B. Doyon, Early Years of the Oblate Missions in Texas and Mexico, EO 8 (1949), s. 325-333; D. Levasseur, Histoire des Missionnaires Oblats de Marie Immaculée, dz. cyt., t. 1, s. 155; Personnel 1895, s. 51. 
rafii Matamoros ${ }^{125}$. Inni głosili słowo Boże bardziej na południu. Pierwszą misję w Meksyku przeprowadzono wiosną 1859 r. w Cruillas (stan Tamaulipas). W 1860 r. oblaci przyjęli parafię w Victorii ${ }^{126}$.

Do swej diecezji zapraszał też oblatów bp Barajas z St-Louis-Potosi ${ }^{127}$. Leflon wspomina, że oblaci pracowali także w Burgos. Mimo dobrych początków gwałtowne prześladowania religijne przyczyniły się do wycofania oblatów z Meksyku. Z Victorii wyrzucono ich 20 grudnia 1861 r., a Matamoros musieli opuścić w roku 1866 . Wbrew niesprzyjającym okolicznościom kontynuowali pracę w Bronsville i na ranczach. W 1864 r. otworzono nawet normalną rezydencję w Agualeguas, skąd opiekowano się sanktuarium i parafią ${ }^{128}$. Na dodatek, jakby mało było kłopotów, po drugiej stronie granicy, w Stanach Zjednoczonych, warunki również bardzo się pogorszyły, ponieważ lata 1861-1865 to czas wojny secesyjnej. Trudno w tym czasie mówić o dużych postępach w pracy apostolskiej. Rozpoczęte prace jednak kontynuowano. Następca bp. Odina w Galveston - bp Dubuis, powiększył pole ich apostolatu na ranczach oraz oficjalnie powierzył misje w Romie oraz od niej zależnych w San Ignatio i Rio Grande City ${ }^{129}$.

Na synodzie w Nowym Orleanie w 1872 r. biskupi wystąpili z propozycją erekcji dystryktu Rio Grande w wikariat apostolski. Zaproponowali też jego objęcie oblatom, ale Administracja Generalna zgromadzenia odrzuciła tę propozycję. Ponownie, za namową biskupa Nanucy, w roku 1880 Kongregacja Rozkrzewiania Wiary ofiarowywała oblatom objęcie wikariatu erygowanego

125 Już w 1857 r. podeszły w latach proboszcz chciał im powierzyć parafię, ale początkowo jej nie przyjęto, gdyż biskup z Monterrey, któremu ona podlegała, był na wygnaniu. W $1861 \mathrm{r}$. powierzył on ją oblatom oficjalnie. Por. T. Ortolan, Cent ans d'Apostolat dans les deux Hémisphères, dz. cyt., t. 2, s. 386-387; J. Leflon, Mgr Eugène de Mazenod, éveque de Marseille, Fondateur des Missionaires Oblats de Marie Immaculée, t. 3, Paris 1966, s. 626-627.

${ }^{126}$ Por. T. Ortolan, Cent ans d'Apostolat dans les deux Hémisphères, dz. cyt., t. 2, s. 388. Cruillas leży ok. $180 \mathrm{~km}$ na południowy zachód od Matamoros. D. Levasseur, Histoire des Missionnaires Oblats de Marie Immaculée, dz. cyt., t. 1, s. 146; J. Leflon, Mgr Eugène de Mazenod..., dz. cyt., s. 628.

${ }^{127}$ Por. J. Leflon, Mgr Eugène de Mazenod..., dz. cyt., s. 625-626, 630; T. Ortolan, Cent ans d'Apostolat dans les deux Hémisphères, dz. cyt., t. 2, s. 391; D. Levasseur, Histoire des Missionnaires Oblats de Marie Immaculée, dz. cyt., t. 1, s. 216.

${ }^{128}$ Por. J. Leflon, Mgr Eugène de Mazenod..., dz. cyt., s. 625-626, 630; T. Ortolan, Cent ans d'Apostolat dans les deux Hémisphères, dz. cyt., t. 2, s. 391; D. Levasseur, Histoire des Missionnaires Oblats de Marie Immaculée, dz. cyt., t. 1, s. 216-217. O działalności Kościoła meksykańskiego w XIX w. por. F. Zubillaga, La Sagrada Congregación de Propaganda Fide y la América Española del Ochocientos, w: Memoria Rerum Sacrae Congregationis de Propaganda Fide. 350 anni a servizio delle Missioni. 1622-1972, t. 3, cz. 1, red. J. Metzler, s. 627-628. Por. też B. Doyon, Early Years of the Oblate Missions..., dz. cyt., s. 333-345.

${ }^{129}$ Por. D. Levasseur, Histoire des Missionnaires Oblats de Marie Immaculée, dz. cyt., t. 1, s. 217. W okolicy Rio Grande w Tamaulipas byli już oblaci w roku 1858 (J. Leflon, Mgr Eugène de Mazenod..., dz. cyt., s. 624). 
na terenach, na których już pracowali. Administracja Generalna również i z tej propozycji nie skorzystała ${ }^{130}$. Przyczyną tych odmów był brak misjonarzy. W latach siedemdziesiątych z powodu braku nowych sił myślano nawet o oddaniu tych misji jezuitom, nie doszło to jednak do skutku. W roku 1884, gdy sytuacja personalna trochę się polepszyła, przyjęto parafię w San Antonio ${ }^{131}$, a nieco później drugi kościół, aby prowadzić apostolat wśród Indian. W 1884 r. przyjęto również ważną parafię w Eagle Pass nad Rio Grande, która stała się centrum okolicznych misji. W rok później założono rezydencję w Rio Grande, a w roku 1899 utworzone zostały na tych terenach jeszcze dwie inne, służące pracy na ranczach w Del Rio i La Lomita (dziś Mission). W głąb Meksyku zaczęto znowu wnikać z początkiem XX w., pierwszy dom założono w $1903 \mathrm{r}$. w Puebla, ale ten okres nie wchodzi w zakres niniejszej pracy ${ }^{132}$.

Choć obszar przy granicy z Kanadą, między Jeziorem Górnym a Montaną, nie był, ściśle biorąc, misyjny, więc tylko wypada wspomnieć, że w latach 1873-1877 oblaci prowadzili kościół w St. Paul oraz dwie rezydencje: w Walhalla i w Pembinie. Usytuowane one były w Dakocie Północnej, a ludność należała częściowo do diecezji St. Paul (Stany Zjednoczone), a częściowo do St-Boniface (Kanada). Obie zostały opuszczone w roku $1876^{133}$.

\section{Oregon}

Na początku XIX w. nazwą Oregon określano cały obszar na zachód od Gór Skalistych, od północnej granicy Kalifornii do Alaski. Oregon omawiany w tym punkcie obejmuje obecne stany Oregon i Waszyngton. W $1818 \mathrm{r}$. uznano 49 równoleżnik za granicę między Stanami Zjednoczonymi a Kanadą; od regionu położonego na zachód od Wielkich Jezior do Gór Skalistych. Aby odeprzeć Rosjan napływających z Alaski, wtedy rosyjskiej, wprowadzono w Oregonie amerykańsko-angielskie kondominium. Dnia 15 czerwca 1846 r. rozdzielono to terytorium na kanadyjskie i amerykańskie, przedłużając granicę na 49 równoleżniku do Oceanu Spokojnego i pozostawiając wyspę Vancouver w posiadaniu brytyjskiej Kanady ${ }^{134}$. Całe terytorium Oregonu zostało ukonstytuowane w wikariat apostolski Oregonu i powierzone biskupowi N. Blanchet 1 grudnia 1843 r. Za jego staraniem 24 lipca 1846 r. ten olbrzymi teren został podzielony na trzy diecezje: Oregon City (archidiecezji bp. N. Blanchet - dziś

${ }^{130}$ Por. D. Levasseur, Histoire des Missionnaires Oblats de Marie Immaculée, dz. cyt., t. 1, s. 217.

${ }^{131}$ San Antonio od 1874 r. było stolicą biskupią, a od 1926 r. jest arcybiskupią (Annuario, s. 575).

132 Por. D. Levasseur, Histoire des Missionnaires Oblats de Marie Immaculée, dz. cyt., t. 1, s. 177 i 221; Personnel 1904, s. 44-46.

${ }^{133}$ Por. D. Levasseur, Histoire des Missionnaires Oblats de Marie Immaculée, dz. cyt., t. 1, s. 230.

${ }^{134}$ Por. L. Bazylow, Historia powszechna 1789-1918, Warszawa $1986^{2}$, s. 303-304. 
Portland in Oregon), Walla Walla (diecezji jego brata bp. M. Blanchet) oraz wyspę Vancouver i kontynentalną Kolumbię Brytyjską (diecezji bp. Demersa - por. wyżej Kolumbia Brytyjska). Biskup N. Blanchet prosił bp. de Mazenoda o misjonarzy w roku 1845 i 1846. Jego brat, bp M. Blanchet, skierował swą prośbę do przełożonego oblatów w Ameryce, o. Guigues'a, który przystał na tę propozycję bez porozumienia z założycielem. Choć bp de Mazenod początkowo odmawiał, to jednak ostatecznie wysłał misjonarzy do diecezji Walla Walla zgodnie z obietnicą daną przez o. Guigues'a. Pierwszych pięciu misjonarzy przybyło do Walla Walla 5 września 1847 r. Biskup M. Blanchet miał wtedy oprócz nich tylko jednego kapłana ${ }^{135}$. Oblaci zajęli się najpierw misjami wśród Indian Yakima mieszkających na północ od rzek Kolumbia i Snake. Jesienią 1847 r. otworzyli tu rezydencję pw. św. Róży, a w następnym roku, nad rzeką Yakima, rezydencję dedykowaną Niepokalanemu Poczęciu oraz drugą, nad rzeką Simcoé, dedykowaną św. Józefowi. Główny dom założyli 14 czerwca 1848 r. nad zatoką Puget, w miejscu dziś zwanym Priest Point, na terenie miasta Olympia, leżącym już w diecezji Oregon City. Ortolan wspomina też o jakiejś stacji misyjnej Ste-Croix nad rzeką Attanem. W 1852 r. otwarto także placówkę wśród szczepu Kajuzów (Cayouses), leżącą bardziej na południe, nad rzeką Umatilla. Ojciec Chirouse otworzył tam ponownie misję Ste-Anne. W końcu, w roku 1858, założono rezydencję w Tulalip, nad rzeką Snohomish ${ }^{136}$.

Praca misyjna na tym terytorium była bardzo trudna z powodu wielkiego ubóstwa środków i wrogiej propagandy kaznodziejów protestanckich wymierzonej w misjonarzy katolickich. Ponadto trwająca w latach 1855-1858 wojna między Indianami i Amerykanami zniszczyła główne misje. Ponadto były nikłe nadzieje na widzialne skutki pracy misyjnej wśród Indian. Poza tym trudności przysparzali także dwaj biskupi, którzy z uporem traktowali misjonarzy jak księży diecezjalnych i nie uwzględniali ich własnego prawa zakonnego ${ }^{137}$.

Wszystko to spowodowało, że oblaci zdecydowali się w 1858 r. skierować swój główny wysiłek ku diecezji bp. Demersa. W roku 1860 opuścili więc dom w Olimpii, kontynuując pracę misyjną jeszcze przez pewien czas z Tulalip. Misja ta miała bowiem pieczę nad czterema rezerwatami: Swinomish,

${ }^{135}$ Por. D. Levasseur, Histoire des Missionnaires Oblats de Marie Immaculée, dz. cyt., t. 1, s. 140; por. W. Henkel, The final Stage of U.S.A. Church's Development under Propaganda Fide, w: Memoria Rerum Sacrae Congregationis de Propaganda Fide..., dz. cyt., s. 710-711; T. Ortolan, Cent ans d'Apostolat dans les deux Hémisphères, dz. cyt., t. 2, s. 310; P. Scharsch, Geschichte der Kongregation der Oblaten der Heiligsten und Unbeflecten Jungfrau Maria, Bd. 1, dz. cyt., s. 292.

${ }^{136}$ Por. T. Ortolan, Cent ans d'Apostolat dans les deux Hémisphères, dz. cyt., t. 2, s. 295-296, 298; D. Levasseur, Histoire des Missionnaires Oblats de Marie Immaculée, dz. cyt., t. 1, s. 141-142.

${ }^{137}$ Por. tamże, s. 141. O napięciach z biskupami, zarówno oblatów, jak i jezuitów, którzy też na tym terenie pracowali, ale wcześniej go opuścili por. G. Carrière, Le père Pascal Ricard, évêque en Orégon?, EO 30 (1971), s. 241-268. 
Lummi-Wagget, Muckleshoot i Port Madison. Jednakże ostatecznie także i tę misję przekazano biskupowi w 1878 r., odpowiadając na bardziej naglące potrzeby w Kolumbii Brytyjskiej ${ }^{138}$.

\section{Alaska}

Ewangelizację Alaski rozpoczął Rosyjski Kościół Prawosławny już w roku $1794^{139}$. Oblaci pracujący nad dolną Mackenzie docierali rzeką Porcupine na jej wschodnie tereny. W 1862 r. o. Séguin dotarł do Fortu Yukon. Szerzej wspomnieć trzeba o wyprawie bp. Clut OMI i o. Lecorre'a przez cały półwysep podjętej w 1873 r. Dnia 15 maja 1873 r. wyruszyli oni z Fortu Yukon i rzeką Jukon przez Nulato, Anvick, Malemuts, Andrealsky i Pastolik dotarli 19 czerwca nad Morze Beringa. Potem udali się na wyspę St-Michel. W lipcu bp Clut wyruszył z powrotem, a o. Lecorre pozostał w Nulato, która miała stać się bazą przyszłych misji na Alasce. Gdy jednak się okazało, że terytorium Alaski nie podlega jurysdykcji wikariusza apostolskiego Athabaska-Mackenzie, lecz biskupa z Vancouver, o. Lecorre opuścił tę stację w roku 1874. Ta trudna i długa wyprawa nie przyniosła zgromadzeniu żadnych bezpośrednich korzyści. W roku 1866 misje na Alasce zostały przez biskupa z Vancouver powierzone jezuitom, a w 1894 r. erygowana została prefektura apostolska Alaski $^{140}$.

\section{Podsumowanie}

Istota działalności misyjnej nie zależy od podziałów terytorialnych. Przypomniał o tym wyraźnie Jan Paweł II w Redemptoris missio. Ponieważ jednak wciąż istnieją kanoniczne określenia dotyczące specyficznych obszarów pracy

${ }^{138}$ Por. D. Levasseur, Histoire des Missionnaires Oblats de Marie Immaculée, dz. cyt., t. 1, s. 142; P. Scharsch, Geschichte der Kongregation der Oblaten der Heiligsten und Unbeflecten Jungfrau Maria, Bd. 2, dz. cyt., s. 424. Szerzej tę pracę omawia G.M. Wagget, The Oblates of Mary Immaculate in the Pacific Northwest of U.S.A. 1847-1878, EO 30 (1971), s. 241-268.

139 Por. A. Kurek, Działalność misyjna prawosławia, „Zeszyty Misjologiczne Akademii Teologii Katolickiej”, t. 2/2, s. 82; tenże, Duchowość misjonarska Kościołów Niekatolickich, „Zeszyty Misjologiczne Akademii Teologii Katolickiej", t. 4, s. 105-106.

${ }^{140}$ Por. P. Duchaussois, Wśród lodów polarnych ..., dz. cyt., s. 357; T. Ortolan, Cent ans d'Apostolat dans les deux Hémisphères, dz. cyt., t. 4, s. 297, 307-308. Ściśle biorąc, o. Lecorre nie był wtedy jeszcze oblatem (choć na ogół się to myli), ale kapłanem diecezjalnym, gdyź śluby zakonne złożył dopiero w 1876 r. (Personnel 1904, s. 70). Szerzej o wyprawie przez Alaskę por. J.E. Champagne, First Attempts at the Evangelization of Alaska, EO 2 (1943), s. 13-22; G. Mousseau, "L'affaire d'Alaska". A propos du voyage de Mgr Clut dans l'Amerique russe en 1872, EO 5 (1946), s. 161-188; A.G. Morice, Histoire de l'Église catholique, vol. 4, s. 344. 
misyjnej, wydaje się, że tego rodzaju geograficzny przegląd jest niezbędnym wstępem do dalszych analiz misjologicznych.

Powyższe zestawienia są przyczynkiem do podjęcia refleksji misjologicznej przynajmniej na trzy tematy. Po pierwsze, systematyzują tereny pracy misyjnej oblatów w XIX w. w Ameryce Północnej. Jest to o tyle ważne, że realia pracy w rozmaitych miejscach bardzo się różniły między sobą. Zupełnie inna była rzeczywistość kościelna w Kanadzie Wschodniej, a inna w Kanadzie Zachodniej i Północno-Zachodniej, nie wspominając już o Stanach Zjednoczonych. Po drugie, spoglądając na misje XIX w. z perspektywy współczesnego nauczania posoborowego, kładącego akcent na wspólnotowy wymiar zakładania Kościoła, łatwo zgubić perspektywę XIX-wiecznej teologii i myśli misyjnej, skoncentrowanej na budowaniu struktury Kościoła i „opanowywaniu” kolejnych ziem, np. w konkurencji z misjonarzami protestanckimi (były to czasy na długo przed rozwojem współpracy ekumenicznej). Jak zauważył cytowany w tekście prof. J.E. Champagne, można podziwiać, w jak szybkim czasie misjonarze oblaci ,zajmowali” kolejne obszary, zakładając swe placówki w miejscach geograficznie strategicznych. Biorąc pod uwagę, że w regionach tych nie było miast, a ludność tam żyjąca (Indianie i Inuici) była w większości przypadków nomadyczna, nie było innej możliwości nawiązywania z nią stałych relacji. W tym względzie przypadek północno-zachodniej Kanady może stanowić świetlany przykład takiego pojmowania misji. Po trzecie, kryterium geograficzne zastosowane $\mathrm{w}$ artykule miało również na celu ukazanie różnorodności sytuacji misyjnych. Zwłaszcza w pierwszej części podkreślone zostało, że nie każdą działalność ewangelizacyjną na tym terenie można nazywać „misyjną”. W Kanadzie Wschodniej istniały już w miarę ustabilizowane struktury kościelne. W 1841 r., czyli w roku przybycia oblatów do Kanady, istniało tam już kilka diecezji, a w większych miastach funkcjonowały dość regularne parafie. Była to praca, którą należałoby określić jako duszpasterską, nie misyjną. Ponieważ oblaci postrzegali siebie bardziej jako misjonarze, więc, poza kilkoma wyjątkami, zajmowali się pracą wśród ludzi żyjących poza miastami (np. Indian wschodniej Kanady). Tekst ukazał wyraźnie, że oblaci jedynie „uzupełniali” swą pracą miejscowy Kościół, ukierunkowany bardziej duszpastersko. Zupełnie inna sytuacja panowała na preriach Kanady Zachodniej i Północno-Zachodniej. Tam trzeba było zakładać Kościół od samego początku, tworząc jego zręby. Na tych terenach pracowało bardzo mało księży diecezjalnych, a jeszcze mniej kapłanów z innych zgromadzeń zakonnych. Oblaci musieli więc podjąc się tworzenia struktur Kościoła we wszystkich wymiarach. Praca w Stanach Zjednoczonych była w tym względzie również zróżnicowana, dlatego uzasadnione było choć skrótowe wyróżnienie trzech obszarów w omówieniu tego rozdziału dziejów oblackich misji w Ameryce Północnej. 


\section{THE AREA OF MINISTRY OF THE MISSIONARY OBLATES OF MARY IMMACULATE IN THE 19TH CENTURY NORTH AMERICA}

\section{SUMMARY}

The article offers an overview of the engagements of the Missionary Oblates of Mary Immaculate in North America in the $19^{\text {th }}$ century. It is basically a geographical survey of the continent focusing on the areas where the Oblates were active in various ministries. In eastern Canada the main centers for the Oblate work were Montreal and Bytown (Ottawa). In western Canada the territories reached by the Oblates included the dioceses of St. Boniface and St. Albert, the apostolic vicariates of Saskatchewan and Athabaska-Mackenzie, and the diocese of New Westminster. Finally the Oblates pursued their missionary goals in the United States, mainly on the border with Mexico, in Oregon and Alaska. Geographical description is followed by the chronological overview of the development of the Oblate religious structures.

Keywords: Missionary Oblates of Mary Immaculate, Oblates, Catholic missions in $19^{\text {th }}$ century, Canada, United States

Słowa kluczowe: Misjonarze Oblaci Maryi Niepokalanej, oblaci, misje katolickie w XIX w., Kanada, Stany Zjednoczone

\section{BIBLIOGRAFIA}

Annuario Pontificio per l'anno 1990, Città del Vaticano 1990.

Arnaud C., Journal de voyage au Labrador, „Vie Oblate Life. Revue trimestrielle publiée par les Oblats de Marie Immaculée de la Province St-Joseph” 34 (1975), s. 45-110.

Baran A., Provision for the Canadian Church. Further development after 1840, w: Memoria Rerum Sacrae Congregations de Propaganda Fide. 350 anni a servizio delle Missioni, 1622-1972, t. 3/1, red. J. Metzler, Rome 1972, s. 749-757.

Bazylow L., Historia powszechna 1789-1918, Warszawa 1986².

Benoît Dom P., Vie de Mgr Taché. Archevêque de St-Boniface, vol. 1, Montréal 1904.

Benoît Dom P., Vie de Mgr Taché, vol. 2, Montréal 1904.

Bulliard R., Misje na krańcu świata, Warszawa 1974.

Campeau L., Les initiatives de la S. Congrégation en faveur de la Nouvelle France, w: Memoria Rerum Sacrae Congregations de Propaganda Fide. 350 anni a servizio delle Missioni, 1622-1972 , t. 1/2, red. J. Metzler, Rome 1972, s. 727-795.

Carrière G., Histoire documentaire de la Congrégation des Missionnaires Oblats de Marie-Immaculée dans l'Est du Canada, t. 1, Ottawa 1957.

Carrière G., Histoire documentaire de la Congrégation des Missionnaires Oblats de Marie-Immaculée dans l'Est du Canada, t. 3, Ottawa 1961.

Carrière G., Histoire documentaire de la Congrégation des Missionnaires Oblats de Marie-Immaculée dans l'Est du Canada, t. 7, Ottawa 1968. 
Carrière G., Histoire documentaire de la Congrégation des Missionnaires Oblats de Marie-Immaculée dans l'Est du Canada, t. 9, Ottawa 1970.

Carrière G., Le père Pascal Ricard, évêque en Orégon?, „Études Oblates. Revue trimestrielle publiée par les Oblats de Marie Immaculée de la Province du Canada” 30 (1971), s. 241-268.

Carrière G., Les Oblats de M.I. dans le Vicariat Apostolique du Labrador (1844-1959), Ottawa 1958.

Champagne J.É., Aux origines de la mission de la rivière Rouge (1818-1845), „Études Oblates. Revue trimestrielle publiée par les Oblats de Marie Immaculée de la Province du Canada" 4 (1945), s. 37-59.

Champagne J.E., First Attempts at the Evangelization of Alaska, „Études Oblates. Revue trimestrielle publiée par les Oblats de Marie Immaculée de la Province du Canada" 2 (1943), s. 13-22.

Champagne J.É., Les missions catholiques dans l'Ouest canadien (1818-1875), Ottawa 1949.

Champagne J.É., Nos premières missions dans l'Ouest canadien (1845-1853), „Études Oblates. Revue trimestrielle publiée par les Oblats de Marie Immaculée de la Province du Canada" 4 (1945), s. 149-173.

Choque C., L'Église et les Inuit, VOL 47 (1988), s. 23-29.

Choquette R., The Oblate Assault on Canada's Northwest, Ottawa 1995.

Coccola N., Oblate Work in Southern British Columbia (1891-1905), VOL 39 (1980), s. 145-165.

Coccola N., The „, Memoirs” of Father Nicolas Coccola, O. M.I. 1883-1890. Pioneer Days in Okanagan and Kootenay, VOL 35 (1976), s. 21-49.

Convention Guigues - de Mazenod, „Études Oblates. Revue trimestrielle publiée par les Oblats de Marie Immaculée de la Province du Canada" 15 (1956), s. 360-364.

D’Herbomez L.J., Rapport sur le vicariat de la Colombie Britannique, „Missions” 17 (1879), s. 410 $-427$.

Dolphin F.J., Biskup Indian Zachodniej Kanady: Vitalis Justin Grandin (1829-1902), Katowice 1993.

Doyon B., Early Years of the Oblate Missions in Texas and Mexico, „Études Oblates. Revue trimestrielle publiée par les Oblats de Marie Immaculée de la Province du Canada" 8 (1949), s. 321-345 .

Duchaussois P., Wśród lodów polarnych u Indjan [sic!-WK] i Eskimosów, tłum. J. Korzeniowska, Krobia 1931.

État général du Personnel de la Congégation des Missionnaire Oblats de Marie Immaculée, no. 4 janvier 1895, Paris 1895.

État général du Personnel de la Congrégation des Missionnaires Oblats de Marie Immaculée, no. 5 - Avril 1899, Paris [1899].

État général du Personnel de la Congrégation des Missionnaires Oblats de Marie Immculée - no 6-décembre 1904, Bar-Le-Duc 1905.

Gratton H., 1841 - A la naissance de nos missions canadiennes, „Études Oblates. Revue trimestrielle publiée par les Oblats de Marie Immaculée de la Province du Canada” 1 (1942), s. 100-117.

Grouard É.J.M., Souvenir de mes soixante ans d'apostolat dans l'Athabaska-Mackenzie, Lyon 1923.

Gstrein H., Nie szczędzil trudu: misjonarze, którzy tworzyli historię: Emil Grouard 1840-1922. Apostol z Athabaski, thum. J. Środulski, Warszawa 1994.

Hamon E., Les Canadiens-français de la Nouvelle-Angletterre, Québec 1891.

Henkel W., The final Stage of U.S.A. Church's Development under Propaganda Fide, w: Memoria Rerum Sacrae Congregations de Propaganda Fide. 350 anni a servizio delle Missioni, 1622-1972 , t. 3/1, red. J. Metzler, Rome 1972, s. 705-728.

Historia Kościoła, t. 4: 1715-1848, red. L.J. Rogier, R. Aubert, M.D. Knowles, thum. T. Szafrański, Warszawa 1987.

Historia Kościoła, t. 5: 1848 do czasów wspótczesnych, red. L.J. Rogier, R. Aubert, M.D. Knowles, thum. T. Szafrański, Warszawa 1985.

http://www.thecanadianencyclopedia.ca/en/article/canadian-american-relations/ [dostęp 2.10.2014]. 
Kluj W., Pole pracy Misjonarzy Oblatów Maryi Niepokalanej na Cejlonie w XIX w., „Annales Missiologici Posnanienses" 17 (2010), s. 51-68.

Kluj W., Pole pracy Misjonarzy Oblatów Maryi Niepokalanej w Afryce w XIX w., „Annales Missiologici Posnanienses" 18 (2012), s. 113-128.

Kowalsky N., L'érection du diocèse de Bytown selon les documents des archives de la Propagande, „Études Oblates. Revue trimestrielle publiée par les Oblats de Marie Immaculée de la Province du Canada" 11 (1952), s. 179-187.

Krótka historia Meksyku, thum. S. Szczurkowska, Warszawa 1986.

Kurek A., Duchowość misjonarska Kościołów Niekatolickich, „Zeszyty Misjologiczne Akademii Teologii Katolickiej”, t. 4, s. 103-115.

Kurek A., Działalność misyjna prawosławia, „Zeszyty Misjologiczne Akademii Teologii Katolickiej", t. 2/2, s. 71-85.

Lamirande É., Le P. A. Trudeau O.M.I. et son refus de l'épiscopat. Pour l'histoire du diocèse de l'île Vancouver, VOL 44 (1985), s. 157-181.

Lamirande É., Les Oblats et la coadjutorerie de Mgr M. Demers. Ile de Vancouver (1861-1865), VOL 45 (1986), s. 371-393.

Lamirande É., Mgr Louis d'Herbomez O.M.I., sa nomination comme vicaire apostolique de la Colombie-Britannique (1863), VOL 47 (1988), s. 45-63.

Leflon J., Mgr Eugène de Mazenod, éveque de Marseille, Fondateur des Missionaires Oblats de Marie Immaculée, t. 3, Paris 1966.

Levasseur D., Histoire des Missionnaires Oblats de Marie Immaculée. Essai de synthèse, t. 1: 1815-1898, Montreal 1983.

Levasseur D., Histoire des Missionnaires Oblats de Marie Immaculée. Essai de synthèse, t. 2: 1898-1985, Montreal 1983-1986.

Levasseur D., Histoire documentaire de la Congrégation des Missionnaires Oblats de Marie-Immaculée dans l'Est du Canada, t. 4, Ottawa 1962.

Magnan J.P., Lettre (25 I 1889), „Missions” 27 (1889), s. 133-164.

Mazenod E. de, Lettres d'obédience des premiers missionnaires Oblats au Canada, „Études Oblates. Revue trimestrielle publiée par les Oblats de Marie Immaculée de la Province du Canada" 1 (1942), s. 124-128.

Morice A.G., Histoire de l'Église catholique dans l'Ouest canadien du Lac Supérieur au Pacifique (1659-1905), t. 1, Winnipeg 1912.

Morice A.G., Histoire de l'Église catholique dans l'Ouest canadien du Lac Supérieur au Pacifique (1659-1905), t. 4, Winnipeg 1923.

Mousseau G., „L'affaire d'Alaska”. À propos du voyage de Mgr Clut dans l'Amerique russe en 1872, „Études Oblates. Revue trimestrielle publiée par les Oblats de Marie Immaculée de la Province du Canada" 5 (1946), s. 161-188.

Ortolan T., Cent ans d'Apostolat dans les deux Hémisphères. Les Oblats de Marie Immaculée durant le premier siècle de leur existence, vol. 2: En dehors de l'Europe (jusqu'à la mort du vénéré Fondateur) 1841-1861, Paris 1915.

Ortolan T., Cent ans d'Apostolat dans les deux Hémisphères. Les Oblats de Marie Immaculée durant le premier siècle de leur existence, t. 4 : Au Canada 1861-1892, Paris 1932.

Philippot A., L'appel et l'envoi des Oblats de Marie Immaculée dans les „Pays d'En-Haut” (1844-1845), „Études Oblates. Revue trimestrielle publiée par les Oblats de Marie Immaculée de la Province du Canada" 9 (1950), s. 73-98.

Rapport de la Province du Canada. Le Chapitre Général de 1873, „Missions de la Congrégation des Missionnaires Oblats de Marie Immaculée” 11 (1873), s. 321-333.

Rapport du vicariat d'Athabaska-Mackenzie, „Missions de la Congrégation des Missionnaires Oblats de Marie Immaculée” 36 (1898), s. 177-192.

Rapport du vicariat de Saint-Albert, „Missions de la Congrégation des Missionnaires Oblats de Marie Immaculée" 36 (1898), s. 193-244. 
Rapport du vicariat de la Saskatchewan, „Missions de la Congrégation des Missionnaires Oblats de Marie Immaculée" 36 (1898), s. 153-176.

Rapport sur le vicariat d'Athabaska-Mackenzie, „Missions de la Congrégation des Missionnaires Oblats de Marie Immaculée" 31 (1893), s. 365-384.

Rapport sur le vicariat de la Colombie-Britannique, „Missions de la Congrégation des Missionnaires Oblats de Marie Immaculée" 31(1893), s. 385-410.

Rapport sur le vicariat de la Saskatchewan, „Missions de la Congrégation des Missionnaires Oblats de Marie Immaculée" 31 (1893), s. 410-422.

Rapport sur le vicariat de Saint-Albert, „Missions de la Congrégation des Missionnaires Oblats de Marie Immaculée" 31 (1893), s. 346-365.

Scharsch P., Geschichte der Kongregation der Oblaten der Heiligsten und Unbeflecten Jungfrau Maria, Bd. 1: Unter dem Stifer. 1816-1861, Maria Engelport 1952.

Scharsch P., Geschichte der Kongregation der Oblaten der Heiligsten und Unbeflecten Jungfrau Maria von ihrem Anfange bis zum Tode des dritten Generalobern, 1816-1897, Bd. 2: Unter den Generalobern P. Joseph Fabre und P. Louis Soullier, 1861-1897, Maria Engelport 1952.

Schulte J., Wielki wódz prerii - Albert Lacombe, Warszawa 1988.

Seumois A., Problem terytorialnej reorganizacji Kongregacji Rozkrzewiania Wiary, w: Kościót na drodze spotkania z trzecim światem, red. B. Gielata, F. Zapłata, Warszawa 1971, s. 25-48.

Tremblay V., Les Oblats au Saguenay, „Études Oblates. Revue trimestrielle publiée par les Oblats de Marie Immaculée de la Province du Canada" 3 (1944), s. 5-20.

Wagget G.M., The Oblates of Mary Immaculate in the Pacific Northwest of U.S.A. 1847-1878, „Études Oblates. Revue trimestrielle publiée par les Oblats de Marie Immaculée de la Province du Canada" 6 (1947), s. 7-88.

Zając P., Kościół katolicki za Kolem Polarnym. Misjonarze Oblaci Maryi Niepokalanej w centralnej Arktyce kanadyjskiej, 1912-2012, Kraków 2012.

Zając P., Spotkania kultur. Katoliccy misjonarze i Ludność Rodzima w Kanadzie w historiografii XIX i XX w., Warszawa 2007.

Zubillaga F., La Sagrada Congregación de Propaganda Fide y la América Española del Ochocientos, w: Memoria Rerum Sacrae Congregationis de Propaganda Fide. 350 anni a servizio delle Missioni. 1622-1972, t. 3, cz. 1, red. J. Metzler, s. 603-636.

O. DR HAB. WOJCIECH KLUJ OMI, PROF. UKSW - wykładowca misjologii na UKSW oraz Wyższym Seminarium Duchownym Misjonarzy Oblatów Maryi Niepokalanej w Obrze (WT UAM). Specjalizował się z misjologii na Uniwersytecie św. Pawła w Ottawie, odbywał też staże misjologiczne w Kanadzie i na Madagaskarze. Opublikował niedawno Kształtowanie się podstawowych tekstów wiary w języku malgaskim, Warszawa 2013. 